\title{
CHEMICALLY MODIFIED CARBOXYPEPTIDASE Y WITH INCREASED AMIDASE ACTIVITY
}

\author{
by \\ KLAUS BREDDAM
}

Department of Chemistry, Carlsberg Laboratory

Gamle Carlsberg Vej 10, DK-2500 Copenhagen Valby

\begin{abstract}
Keywords: Peptide synthesis, amidase, carboxypeptidase $\mathrm{Y}$, serine carboxypeptidase, chemical modification, kinetics, iodoacetamide, phenacylbromide
\end{abstract}

Treatment of carboxypeptidase $\mathrm{Y}$ with ${ }^{14} \mathrm{C}$-iodoacetamide caused a drastic reduction in the peptidase activity towards FA-Phe $\_$Leu-OH while the esterase activity towards FA-Phe $\searrow$ OMe, the amidase activity towards FA-Phe ${ }^{-} \mathrm{NH}_{2}$ and the peptidyl amino acid amide hydrolase activity towards $\mathrm{FA}-\mathrm{Phe}=\mathrm{Gly}-\mathrm{NH}_{2}$ were much less affected. The loss of peptidase activity could be correlated with the incorporation of a single equivalent of reagent and it was demonstrated that the site of reaction was a methionyl residue, thus forming a sulfonium derivative. Analogous methionyl modifications were performed: carboxypeptidase $Y$ modified with phenacylbromide hydrolysed substrates with bulky leaving groups in the $\mathrm{P}_{1}^{\prime}$ position, i.e. $-\mathrm{OEt},-\mathrm{OBzl}$, -Gly- $\mathrm{NH}_{2}$, -Gly-OH, and -Leu-OH, at reduced rates while substrates with small groups in that position, i.e. -OMe and $-\mathrm{NH}_{2}$, were hydrolysed with increased rates. These results indicate that the methionyl residue modified by phenacylbromide is located in the $S_{1}$ binding site of the enzyme. Similar results were obtained with carboxypeptidase $Y$ modified with m-nitrophenacylbromide and p-nitrophenacylbromide.

The increase in amidase activity and decrease in peptidyl amino acid amide hydrolase activity of carboxypeptidase $Y$ following modification with phenacylbromide, $\mathrm{m}$-nitrophenacylbromide, and $\mathrm{p}$-nitrophenacylbromide was exploited in deamidation of peptide amides. These modified enzymes deamidated peptide amides with the exception of those containing a C-terminal glycyl or seryl residue in yields of $80-100 \%$ which is significantly higher than with unmodified carboxypeptidase $\mathrm{Y}$.

Abbreviations: $\mathrm{Bz}=\mathrm{N}$-benzoyl; $\mathrm{Bzl}=$ benzyl; Caps $=$ cyclohexylaminopropane sulfonic acid; $\mathrm{CPD}-\mathrm{Y}=$ carboxypeptidase $\mathrm{Y} ; \mathrm{DMF}=\mathrm{N}, \mathrm{N}$-dimethylformamide; EDTA = ethylene diamine tetraacetic acid, sodium salt; FA = furylacryloyl; Hepes $=\mathrm{N}$-2-hydroxyethylpiperazine-N-2-ethane sulfonic acid; $\mathrm{HPLC}=$ high performance liquid chromatography; IAA-CPD-Y = CPD-Y modified with iodoacetamide; Mes $=2$-(N-morpholino)ethane sulfonic acid; m-NPAB-CPD-Y = CPD-Y modified with meta-nitrophenacylbromide; PAB-CPD-Y = CPD-Y modified with phenacylbromide; $p$-NPAB-CPD- $Y=C P D-Y$ modified with para-nitrophenacylbromide; $Z=N$-carbobenzoxy. Amino acids abbreviated in upper case refer to the L-enantiomer and those in lower case refer to the D-enantiomer. Other abbreviations of amino acids, amino acid derivatives and peptides are according to the guidelines of the IUPAC-IUB Commision on Biochemical Nomenclature. The binding site notations for the enzyme is that of SCHECHTER and BERGER (27). Accordingly, the binding site for the C-terminal amino acid residue of the substrate is denoted $S_{i}^{\prime}$ and those for the amino acid residues in the amino-terminal direction away from the scissile bond are denoted $S_{1}, S_{2}, \ldots, S_{1}$. Amino acid residues in the substrate are referred to as $P_{1}, P_{2}, \ldots . P_{i}$ and $P_{i}$ in correspondence with the binding site. 


\section{INTRODUCTION}

The capability of proteolytic enzymes to catalyze the synthesis of peptide bonds has been systematically studied over the past decade with the aim of elucidating their potential use in production of biologically active peptides (13). Among these enzymes CPD-Y is particularly useful in step-wise peptide synthesis since it can be employed to elongate a peptide chain by a single amino acid residue. This can be achieved by aminolysis of peptide esters in three different ways (Scheme l) using amino acids (Reaction Ia), amino acid methyl esters (Reaction II) or amino acid amides (Reaction IIIa) as nucleophiles. The yields vary of the peptides and peptide esters obtained by Reactions Ia and II, respectively, but rarely exceed $60 \%(5,7,30,31,32)$. In contrast, by Reaction IIIa peptide amides are synthesized in yields of $85-95 \%$ (32). A peptide ester produced in Reaction II can serve directly as substrate in a subsequent elongation step and a peptide produced in Reaction Ia is easily converted to a peptide ester (Reaction Ib) while elongation of a peptide amide produced in Reaction IIIa requires that it is deamidated (Reaction IIIb) prior to esterification (Reaction

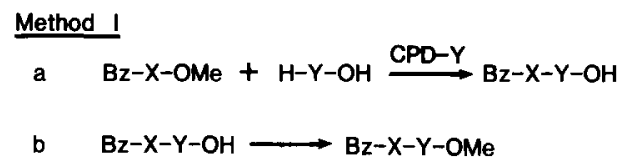

Scheme 1. Three different ways of performing one elongation step in CPD.Y catalyzed peptide syntesis. $\mathrm{Bz}-\mathrm{X}$-OMe represents the peptide ester functioning as acyl-component in the reaction and $\mathrm{H}-\mathrm{Y}-\mathrm{OH}, \mathrm{H}-\mathrm{Y}$ $\mathrm{OMe}$, and $\mathrm{H}-\mathrm{Y}-\mathrm{NH}_{2}$ represent the amino acid, amino acid methyl ester, and amino acid amide, respectively, functioning as amine components in the reaction. Bz-X-Y-OMe represents the acyl-component in the subsequent elongation reaction. The esterification reactions Ib and IIIc are performed chemically.

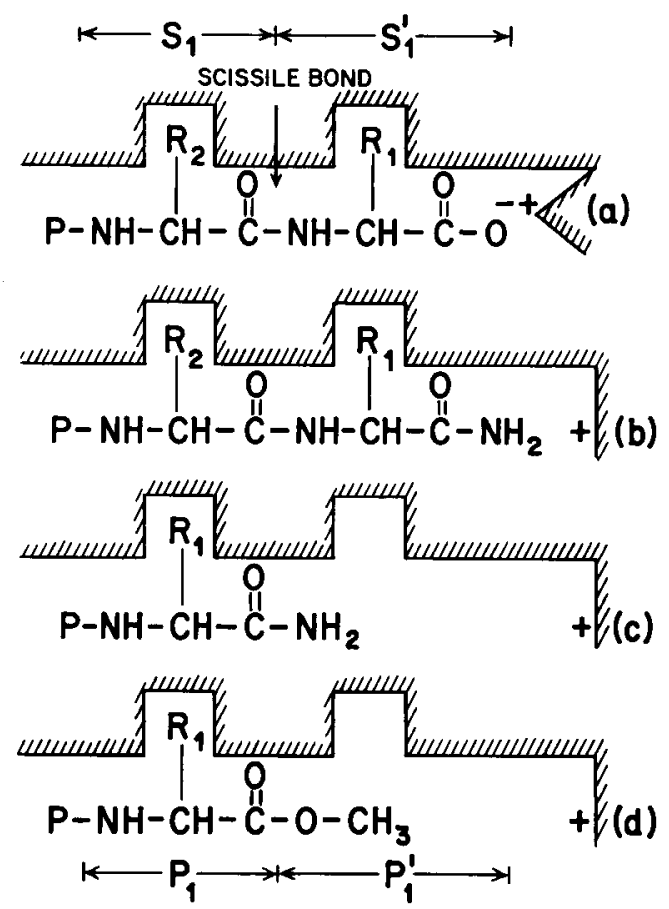

Figure 1. Schematic presentation of the binding regions in the active site of CPD-Y. The binding notation is that of SCHECHTER and BERGER (see abbreviations), and the dead-end structure of the active site is assumed to account for the exo-peptidase specificity of CPD-Y. The figure demonstrates conceivable binding modes of peptides, peptide amides, and peptide esters, accounting for peptidase (a), peptidyl amino acid amide hydrolase (b), amidase (c) and esterase (d) activities of the enzyme.

IIIc). Chemical methods are not suitable for deamidation reactions and no enzymes have been described which specifically release $\mathrm{NH}_{3}$ from peptide amides. Serine and sulfhydryl proteases exhibit amidase activity but they predominantly cleave internal peptide bonds and are consequently of limited value in the deamidation of polypeptide amides. Serine carboxypeptidases, e.g. CPD-Y and malt carboxypeptidase, have similar limitations since they in addition to amidase activity also exhibit peptidyl amino acid amide hydrolase activity and accordingly release both $\mathrm{NH}_{3}$ and the C-terminal amino acid amide $(4,8,9)$. Hence, in spite of the high yield of Reaction IIIa the overall yield of an elongation step according to Method III usually 
is no higher than those typical of Methods I and II. Thus, it appears that a more wide-spread use of CPD-Y in peptide synthesis might be stimulated by the development of an improved method for deamidation of peptide amides.

It has previously been demonstrated that the specificity of proteolytic enzymes may be altered by chemical modifications of amino acid sidechains located at their binding sites $(3,6,16,29)$ and by addition of substances which specifically bind to such sites, i.e. modifiers, $(9,17)$. Similar approaches might possibly be applied to alter the leaving group specificity of a serine carboxypeptidase such that it only releases $\mathrm{NH}_{3}$ from peptide amides and not amino acid amides. In terms of binding sites, the serine carboxypeptidases probably exhibit similarities with (metallo) carboxypeptidase $\mathrm{A}$ which possesses only a single binding site for the leaving group, i.e. $S_{1}$, which is located in a dead-end pocket in the enzyme (23). A postulated binding region of the active site of serine carboxypeptidases is schematically illustrated in Figure 1 which also suggests how peptides (a), peptide amides (b, c) and peptide esters (d) might be bound to the enzyme. It should be noted that the ability of the enzyme to release ammonia (c) and amino acid amides (b) might be explained from binding of the C-terminal amino acid residue of peptide amides to either the $S_{1}^{\prime}$ or the $S_{1}$ binding sites. It remains to be established whether the interaction between serine carboxypeptidases and peptide substrates with a free carboxylate group is dependent on a positively charged binding site in analogy with carboxypeptidase A $(23,24)$. KUHN et al. (19) suggested an arginine side-chain to function in this capacity in CPD-Y but studies in the present laboratory have not confirmed this (K. BREDDAM, unpublished results). However, regardless of the possible existence of a positively charged binding site it would appear, from steric considerations, that in the case a group might be introduced in the $S_{1}^{\prime}$ binding site it might adversely affect its ability to release amino acids (a) and amino acid amides (b) without to the same extent affecting its ability to release the less bulky $-\mathrm{NH}_{2}(\mathrm{c})$ and $-\mathrm{OCH}_{3}(\mathrm{~d})$.

In a recent paper from this laboratory (9) it was demonstrated that phenylguanidine binds to the $S_{1}^{\prime}$ binding site of malt carboxypeptidase in such a manner that the amidase activity was increased while the peptidyl amino acid amide hydrolase and peptidase activities were decreased with the result that malt carboxypeptidase catalyzed deamidation reactions with higher yields. Although the broad side-chain specificity of malt carboxypeptidase (9) might be useful in deamidation reactions, viz. deamidation of peptide amides with C-terminal lysyl, arginyl, or histidyl residues, this enzyme is presently available in only small quantities. CPD-Y is available in much larger quantities, but phenylguanidine has unfortunately no effect on this enzyme. However, KUHN et al. (19) has shown that a methionyl residue in CPD-Y can be alkylated by iodoacetamide with the result that the activity of the enzyme towards a peptide substrate ((a) in Figure 1), was drastically reduced while the activity towards an ester substrate, ((d) in Figure 1) remained essentially unchanged. Consequently, it may be suspected that this residue is located in the $S_{1}^{\prime}$ binding site and hence, this derivative of CPD-Y was of potential interest as a more specific deamidase. In the present paper this and other methionyl modified derivatives of CPD-Y have been prepared and tested with respect to specificity in deamidation reactions. It is demonstrated that CPD-Y modified with phenacylbromide has enzymatic characteristics which renders it a promising tool as a deamidase in enzymatic peptide synthesis.

\section{MATERIALS AND METHODS}

\subsection{Materials}

The following compounds were synthesized as previously described: Bz-Phe-His- $\mathrm{NH}_{2}$ (9), Bz-Ala-Val- $\mathrm{NH}_{2}$ (4), Bz-Ala-Ile- $\mathrm{NH}_{2}$ (4), BzAla-Phe- $\mathrm{NH}_{2}$ (4), Bz-Ala-Ala- $\mathrm{NH}_{2}$ (4), Bz-AlaThr- $\mathrm{NH}_{2}$ (4), Bz-Ala-Leu-NH $\mathrm{N}_{2}$ (4), CABS-Sepharose (8), FA-Phe-NH $\mathrm{N}_{2}(8)$, FA-Phe-Gly-NH (8) and FA-Phe-Gly-OH (8). FA-Phe-OEt, FAAla-OEt, FA-Ala-OBzl, FA-Leu-NH $\mathrm{N}_{2}$, FA-Val$\mathrm{NH}_{2}$, FA-Phe-Val-OH and FA-Phe-Leu-OH were prepared according to the methods outlined by BLUMBERG and VAlLeE (3): $2 \mathrm{mmol}$ FA-N-hydroxysuccinimide ester was dissolved in $5 \mathrm{ml}$ dioxane and $5 \mathrm{ml}$ water containing 4 mmol $\mathrm{NaHCO}_{3}$ and $2 \mathrm{mmol}$ H-Phe- 
OEt $\cdot \mathrm{HCl}, \mathrm{H}$-Ala-OEt $\cdot \mathrm{HCl}, \mathrm{H}-\mathrm{Ala}-\mathrm{OBzl} \cdot \mathrm{HCl}$, $\mathrm{H}$-Leu- $\mathrm{NH}_{2} \cdot \mathrm{HCl}, \mathrm{H}-\mathrm{Val}-\mathrm{NH}_{2} \cdot \mathrm{HCl}, \mathrm{H}$-PheVal-OH or $\mathrm{H}-\mathrm{Phe}-\mathrm{Leu}-\mathrm{OH} \cdot \mathrm{HCl}$. After four hours the dioxane was evaporated and the synthesized substrates were recrystallized from ethanol/water yielding compounds of higher than $98 \%$ purity as judged from HPLC analysis and amino acid analysis. FA-Phe-Val- $\mathrm{NH}_{2}$ was prepared by enzymatic synthesis: $1 \mathrm{~g} \mathrm{H}-\mathrm{Val}-\mathrm{NH}_{2}$ was dissolved in $40 \mathrm{ml} 1 \mathrm{mM}$-EDTA and $\mathrm{pH}$ was adjusted to 9.5 by addition of $\mathrm{NaOH} .10 \mathrm{mg}$ CPD-Y was added followed by dropwise addition over $10 \mathrm{~min}$ of $300 \mathrm{mg}$ FA-Phe-OMe dissolved in $5 \mathrm{ml}$ methanol. A precipitate was formed during the reaction which was terminated after $10 \mathrm{~min}$ by addition of $200 \mathrm{ml}$ $\mathrm{CH}_{3} \mathrm{CN}$. The reaction mixture was evaporated to dryness and subsequent recrystallization from ethanol/water yielded the pure product. Similar procedures were used to synthesize $\mathrm{Bz}-\mathrm{Phe}-\mathrm{Gln}$ $\mathrm{NH}_{2}$ from Bz-Phe-OEt and $\mathrm{H}-\mathrm{Gln}-\mathrm{NH}_{2} \cdot \mathrm{HCl}$ and Bz-Arg-Phe-Val- $\mathrm{NH}_{2}$ from Bz-Arg-PheOEt and $\mathrm{H}-\mathrm{Val}-\mathrm{NH}_{2} \cdot \mathrm{HCl}$. However, attempts to crystallize Bz-Arg-Phe-Val- $\mathrm{NH}_{2}$ failed and this substrate was consequently used as a lyophilized $90 \%$ pure preparation containing 10\% Bz-Arg-Phe-OH. Melting points: FA-Phe-OEt: 84-85 ${ }^{\circ} \mathrm{C}$, FA-Ala-OEt: $78-78.5{ }^{\circ} \mathrm{C}$, FA-Leu$\mathrm{NH}_{2}: 177-178{ }^{\circ} \mathrm{C}$, FA-Val-NH $: 241-243{ }^{\circ} \mathrm{C}$, FA-Ala-OBzl: $90-91{ }^{\circ} \mathrm{C}$, FA-Phe-Val-OH: 210 $211{ }^{\circ} \mathrm{C}$, FA-Phe-Leu-OH: $102-104{ }^{\circ} \mathrm{C}$, FA-PheVal- $\mathrm{NH}_{2}$ and Bz-Phe-Gln-NH $\mathrm{NH}_{2}:>250^{\circ} \mathrm{C}$.

Biogel P-4 was obtained from Biorad, USA, and Sepharose 4B from Pharmacia, Sweden. CPD-Y and Bz-Arg-Phe-OEt were obtained from Carlsberg Biotechnology Ltd. A/S, Tagensvej 16, DK-2200 Copenhagen N. FA-PheOMe, FA-Leu-OMe, H-Ala-OBzl - HCl, H-Val$\mathrm{NH}_{2} \cdot \mathrm{HCl}, \mathrm{H}$-Leu- $\mathrm{NH}_{2} \cdot \mathrm{HCl}$, Z-ala-Phe-OH, Z-Ala-Gly- $\mathrm{NH}_{2}$, Z-Ala-Ala- $\mathrm{NH}_{2}$, Z-Phe-Gly$\mathrm{NH}_{2}$, Z-Ala-Ala-OMe, and FA-N-hydroxysuccinimide ester were obtained from Bachem, Switzerland. Phenacylbromide was from Fluka, Switzerland. p-nitrophenacylbromide and $\mathrm{m}$ nitrophenacylbromide were from ICN Pharmaceuticals, USA and $\alpha$-Bromo-2'acetonaphtone (naphtacylbromide) was from EGA Chemie, $W$. Germany. Z-Ala-Ser-NH $\mathrm{N}_{2}$, Z-Ala-Met-NH $\mathrm{NH}_{2}$ ZVal-Ala- $\mathrm{NH}_{2}$, Z-Ile-Ala-NH${ }_{2}$, Z-Ala-Val-OMe, Z-Ala-Ile-OMe，Z-Ala-Met-OMe，Z-Ala-Gly-
OMe, H-Phe-OEt $\cdot \mathrm{HCl}$ and Z-Val-Gly- $\mathrm{NH}_{2}$ were obtained from Vega Biochemicals, USA. Iodoacetamide, H-Phe-Val-OH, H-Ala-OEt, Mes, Caps and Hepes were products of Sigma, USA. ${ }^{14} \mathrm{C}$-iodoacetamide was obtained from Amersham, England. All other chemicals and solvents were of analytical purity and obtained from Merck, W. Germany.

\subsection{Methods}

\subsubsection{Modifications of CPD-Y}

The influence of various reagents on the esterase, amidase, peptidyl amino acid amide hydrolase and peptidase activities of CPD-Y was studied using FA-Phe-OMe, FA-Phe- $\mathrm{NH}_{2}$, FA$\mathrm{Phe}=\mathrm{Gly}-\mathrm{NH}_{2}$ and FA-Phe-Leu-OH as substrates, respectively. The assay with FA-PheLeu-OH was performed in $0.05 \mathrm{M}-\mathrm{Mes}, 1 \mathrm{~mm}$ EDTA, $\mathrm{pH} 6.5$, and with the other substrates $0.05 \mathrm{M}$-Hepes, $1 \mathrm{mM}$-EDTA, pH 7.5 was used. The assay mixture consisted of $965 \mu \mathrm{l}$ buffer, 25 $\mu 112 \mathrm{~mm}$-substrate dissolved in methanol and $10 \mu \mathrm{l}$ aliquots of the reaction mixture, added directly or after an appropiate dilution in water. The rate of hydrolysis was followed spectrophotometrically at $337 \mathrm{~nm}$, using a Cary 219 spectrophotometer, thermostated at $25^{\circ} \mathrm{C}$. All modifications of CPD-Y were carried out in 0.03 $\mathrm{M}-\mathrm{NaH}_{2} \mathrm{PO}_{4}, 0.12 \mathrm{M}-\mathrm{NaCl}$, pH 6.5 at room temperature using an enzyme concentration of $6.2 \mathrm{mg} / \mathrm{ml}$. Control reactions without reagent added ensured that the enzyme was stable under these conditions. With the exception of a six fold higher enzyme concentration the reaction conditions were essentially as those described by KUHN et al. (19). Reactions were terminated by separating enzyme from reagent by gelfiltration on Biogel P-4, equilibrated with water. The bed volume was 20-30 fold the volume of the sample applied. The modified preparations of CPD-Y were stored frozen in water at $-18^{\circ} \mathrm{C}$.

Modification of CPD-Y in the presence of inhibitor was performed by addition of $1 \mathrm{M}-\mathrm{Z}$ ala-Phe-OH in ethanol to the reaction medium, followed by readjustment of $\mathrm{pH}$.

\subsubsection{Characterization of modified CPD-Y}

The preparations of modified enzyme ob- 
tained after gelfiltration were analyzed for amino acid composition and incorporation of radioactively labelled reagent (only for iodoacetamide). The amino acid composition was determined after acid hydrolysis for 24 hours in vacuo using a Durrum D 500 amino acid analyzer. During acid hydrolysis approximately $20 \%$ of the iodoacetamide methionine sulfonium derivative formed by alkylation reactions reverts to free methionine (14). The values for modified methionine residues listed in the present paper are uncorrected and consequently slightly underestimated. The content of free cysteine was estimated by titration with para-hydroxymercuribenzoate as described by RIORDAN and VALLEE (24).

${ }^{14} \mathrm{C}$-measurements were performed by liquid scintillation using a Beckman scintillation counter, Model LS 3155 T. The stoichiometry of incorporated reagent was based on spectrophotometrically determined enzyme concentrations using $\mathrm{A}_{280}=14.8$ (18).

CPD-Y treated with alkylating reagents was subjected to thiolysis reactions in order to regenerate methionyl residues from their corresponding sulfonium salts. The conditions used were essentially those employed by NAIDER and BOHAK (21). Thiolysis of iodoacetamide treated enzyme was performed at $1 \mathrm{mg} / \mathrm{ml}$ enzyme in $0.005 \mathrm{M}-\mathrm{Na}_{2} \mathrm{~B}_{4} \mathrm{O}_{7}, 0.14 \mathrm{M}$-mercaptoethanol, $\mathrm{pH}$ 9.0. With PAB-CPD-Y the reaction was performed at $0.17 \mathrm{mg} / \mathrm{ml}$ enzyme in $0.05 \mathrm{M}$ $\mathrm{NaH}_{2} \mathrm{PO}_{4}, 7$ mM-mercaptoethanol, $\mathrm{pH}$ 7.5. The activity of the enzyme towards FA-Phe-Leu-OH (see section 2.2.l) was followed during the reaction.

\subsubsection{Affinity chromatography}

Modified CPD-Y was separated from unmodified enzyme by affinity chromatography on CABS-Sepharose. Preparations of modified enzyme obtained by gelfiltration (see section 2.2 .1 ) were adjusted to $0.02 \mathrm{M}$-sodium acetate $\mathrm{pH} 4.8$ and applied to a CABS-Sepharose column, equilibrated with the same buffer at a load of 2.5-2.7 $\mathrm{mg}$ enzyme per $\mathrm{ml}$ affinity resin. The column was washed with 0.02 M-sodium acetate, $\mathrm{pH} 4.8$ and the modified enzyme was specifically eluted with the same buffer contain- ing $0.5 \mathrm{M}-\mathrm{NaCl}$. Unmodified CPD-Y could subsequently be eluted with $0.05 \mathrm{M}-\mathrm{NaH}_{2} \mathrm{PO}_{4}$, $\mathrm{pH}$ 7.5. Control experiments indicated that unmodified CPD-Y was not released from the affinity column by $0.02 \mathrm{M}$-sodium acetate, 0.5 $\mathrm{M}-\mathrm{NaCl}, \mathrm{pH} 4.8$.

\subsubsection{Determination of kinetic constants}

The kinetic constants for the hydrolysis of various FA- peptide and ester substrates by unmodified CPD-Y as well as the CPD-Y derivatives isolated by affinity chromatography were determined from Lineveawer-Burk plots. Such determinations were not possible with peptide amides due to their low solubility combined with high $\mathrm{K}_{\mathrm{m}}$ values. With these substrates only $\mathrm{k}_{\mathrm{cal}} /$ $\mathrm{K}_{m}$ was determined by following the hydrolysis to completion at a single concentration of substrate and using the integrated form of the Michaelis-Menten equation as described in reference 28. With FA-Phe-Gly- $\mathrm{NH}_{2}$ and FAPhe-Val- $\mathrm{NH}_{2}$ direct amino acid analysis of the assay mixture ascertained that the enzyme only released $\mathrm{H}-\mathrm{Gly}-\mathrm{NH}_{2}$ and $\mathrm{H}-\mathrm{Val}-\mathrm{NH}_{2}$, respectively, and not $\mathrm{NH}_{3}$ followed by the C-terminal amino acid. Hydrolysis rates were determined spectrophometrically at $329-358 \mathrm{~nm}$ and $25^{\circ} \mathrm{C}$. Peptide substrates were assayed in $0.05 \mathrm{M}-\mathrm{Mes}$, 1 mM-EDTA, pH 6.5 whereas ester and amide substrates were assayed in $0.05 \mathrm{M}$-Hepes, 1 mM-EDTA, pH 7.5.

\subsubsection{Stability of CPD-Y derivatives}

The stability of the CPD-Y derivatives isolated by affinity chromatography was investigated at different $\mathrm{pH}$ values by incubating the enzymes at $25{ }^{\circ} \mathrm{C}$ in a concentration of $0.1-0.2$ $\mathrm{mg} / \mathrm{ml}$ in the following buffers: $0.05 \mathrm{M}$-Mes, 1 mM-EDTA, pH 5.0; 0.05 M-Hepes, $1 \mathrm{mM}-$ EDTA, pH 7.5; 0.05 M-2-amino-2-methyl-propanediol, pH 9.0; 0.05 M-Caps, 1 mM-EDTA, $\mathrm{pH} 10.0$. The activity towards FA-Phe-OMe was followed as a function of time and the assays were performed in the same buffer as the incubation. 


\subsubsection{Deamidation of peptide amides and removal of ester groups from peptide es- ters}

All deamidation reactions were performed at 2 mM-substrate concentration in $10 \% \mathrm{DMF}, 2$ mM-EDTA, $\mathrm{pH} 7-10$, using various concentrations of CPD-Y or the CPD-Y derivatives purified by chromatography on CABS-Sepharose. The peptide amide was added to the reaction mixture from a $20 \mathrm{~mm}$-solution in DMF and $\mathrm{pH}$ was controlled in a $\mathrm{pH}$ stat. The reaction volume was $1 \mathrm{ml}$. The removal of ester groups from peptide esters by CPD-Y and PAB-CPD-Y was performed at $\mathrm{pH} 7.5$ using identical conditions. During the reaction aliquots were removed for determination of the composition of the reaction mixture by HPLC, using a C-18 reverse phase column, a Radial Compression Module and other equipment from Waters Associates, USA. The following eluant system was used: 50 mM-triethyl ammonium phosphate, $\mathrm{pH} 3.0$ (Abuffer) and $50 \mathrm{~mm}$-triethyl ammonium phosphate, $\mathrm{pH} 3.0$ in $50 \% \mathrm{CH}_{3} \mathrm{CN}$ (B-buffer) employing various linear or concave gradients. All separations were carried out at room temperature and monitored at $254 \mathrm{~nm}$. The per cent composition of the reaction mixtures could be calculated directly from the integrated peak areas since all components had the $\mathrm{Bz}-$, $\mathrm{Z}$-, or FA- group as common chromophore. Products not identifiable by chromatography of known standard compounds were collected and identified by amino acid analysis after acid hydrolysis. The deamidation product is the product formed by release of ammonia from the peptide amide, and the yield of deamidation is calculated as the percentage of this product relative to all products formed in the reaction, i.e. unconsumed substrate was disregarded in the calculations. The yield of deesterification was calculated in the same manner.

\section{RESULTS}

\subsection{Chemical modifications of CPD-Y}

$\mathrm{CPD}-\mathrm{Y}$ was modified by ${ }^{14} \mathrm{C}$-iodoacetamide under conditions similar to those described by KuHN et al. (19) and within four hours the peptidase activity towards FA-Phe-Leu-OH had decreased to $10 \%$ of the control (Figure $2 \mathrm{~A}$ ).

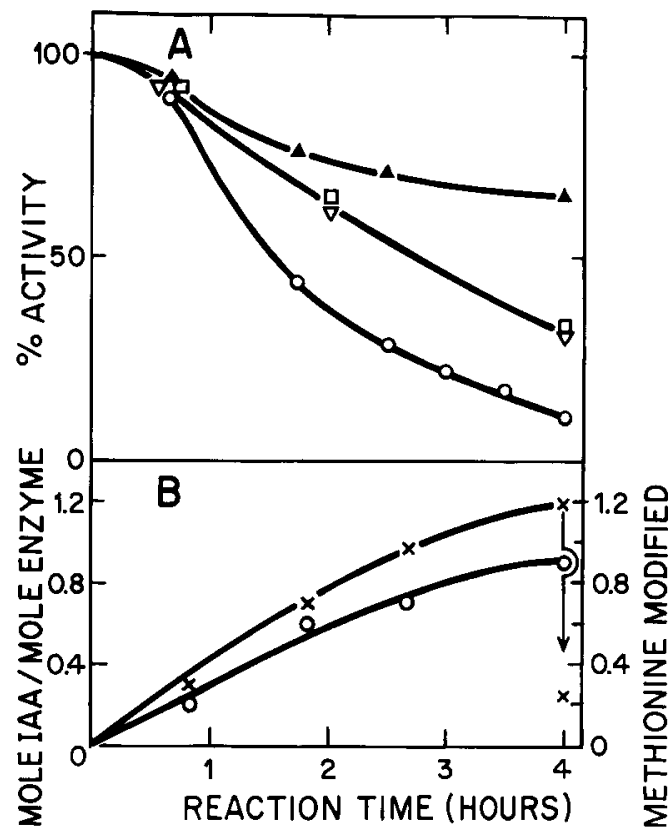

Figure 2. Modification of CPD-Y with ${ }^{14} \mathrm{C}$-iodoacetamide. Reaction conditions: $6.2 \mathrm{mg} / \mathrm{ml}$ CPD-Y, 0.03 $\mathrm{M}-\mathrm{NaHPO}_{4}, 0.12 \mathrm{M}-\mathrm{NaCl}, 0.18 \mathrm{M}$-iodoacetamide, $\mathrm{pH}$ 6.5 . The activities of the enzyme towards FA-Phe ${ }^{\frac{1}{L} \text { Lu- }}$ $\mathrm{OH}(-\mathrm{O}-\mathrm{O}-)$, FA-Phe $\mathrm{OMMe}^{(-\Delta-\Delta-)}$, FA-Phe ${ }^{\ddagger} \mathrm{Gly}-$ $\mathrm{NH}_{2}(-\nabla-\nabla-)$ and FA-Phe $\mathrm{NH}_{2}(-\square-\square-)$ were assayed during the reaction (Panel $A$ ). At different times aliquots of the reaction mixture were desalted and the radioactivity as well as amino acid composition of the modified enzyme determined (Panel B). The radioactivity was expressed as mole reagent incorporated per mole enzyme $(-x-x-)$. The amino acid composition indicated that only methionine was modified during the reaction, and the results were expressed as number of methionyl residues modified per enzyme molecule (-O-O-). Thiolysis of the modified enzyme caused a reduction in the radioactivity count (indicated by an arrow). The thiolysis reaction was performed for 5 hours under the following conditions:

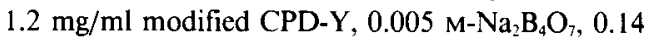
$\mathrm{M}$-2-mercaptoethanol, $\mathrm{pH}$ 9.0. A longer reaction time did not reduce the radioactivity of the enzyme further.

Simultaneously, the esterase activity towards FA-Phe-OMe decreased to $65 \%$ while the amidase and peptidyl amino acid amide hydrolase activities towards FA-Phe $-\mathrm{NH}_{2}$ and FA-PheGly- $\mathrm{NH}_{2}$, respectively, decreased to approximately $30 \%$. The amino acid composition and radioactivity content of the modified enzyme, 
determined as described in section 2.2 .2 , indicated that the modified enzyme only differed from unmodified CPD-Y with respect to the methionine content, while the single sulfhydryl group of the enzyme remained unmodified. The loss of $90 \%$ peptidase activity was correlated with the loss of 0.9 methionine (uncorrected for regeneration of methionine during acid hydrolysis, see section 2.2.2) and with the incorporation of 1.2 equivalent of reagent as determined from the radioactivity measurements (Figure 2B). These results indicate that it is modification of a single methionyl residue with iodoacetamide to yield a carboxymethylmethionine sulfonium ion which drastically alters the enzymatic properties of the enzyme.

Methionyl residues can be regenerated from their sulfonium salts by treatment with thiol compounds without affecting the products which may be formed by alkylation of other amino acid side-chains, i.e. Cys, His, Lys, Glu, and Asp (21). Thus, provided a methionyl residue is the site of reaction with iodoacetamide treatment with thiols should release the radioactive label attached to the enzyme. As expected, treatment with mercaptoethanol for five hours under the conditions described by NAIDER et al. (21) resulted in a loss of $80 \%$ of the label attached to the enzyme (Figure 2B). A longer reaction time did not change this loss further, suggesting that of the 1.2 equivalents of reagent incorporated into the enzyme 0.95 equivalent was located on a methionyl residue while the residual 0.25 equivalent was attached to other residues. However, the activity was not regenerated with the loss of the label, presumably because the high concentration of mercaptoethanol $(0.12 \mathrm{M})$ needed for the thiolysis reaction had denatured the enzyme.

When the reaction was performed in the presence of $37 \mathrm{mM}$ of the competitive inhibitor Z-ala-Phe-OH (1) the activities of CPD-Y were not affected by iodoacetamide within four hours using the conditions listed in Figure 2. The amino acid analysis of the enzyme treated in this fashion did not deviate from that of unmodified CPD-Y. Thus, Z-ala-Phe-OH protected the enzyme towards reaction with iodoacetamide, suggesting that the methionyl residue, modified by this reagent in the absence of
$\mathrm{Z}$-ala-Phe- $\mathrm{OH}$, is located in the active site of the enzyme.

In an attempt to produce derivatives of CPD$\mathrm{Y}$ which retained more of their amidase and esterase activities, CPD-Y was modified with other alkylating reagents which attack methionyl residues and form alkyl sulfonium derivatives (21). Treatment of CPD-Y with phenacylbromide, $\mathrm{p}$-nitrophenacylbromide, and $\mathrm{m}$ nitrophenacylbromide increased the amidase activity and reduced the peptidase and peptidyl amino acid amide hydrolase activities (Figure $3 \mathrm{~A}-\mathrm{C}$ ). However, the effects on the esterase activity depended on the reagent: With phenacylbromide and p-nitrophenacylbromide it increased to $110 \%$ and $240 \%$, respectively, while with $\mathrm{m}$-nitrophenacylbromide it decreased to $70 \%$. Treatment with naphtacylbromide caused a reduction in all activities and consequently, this reaction was not studied further. The preparations of modified CPD-Y, obtained by gelfiltration of the reaction mixture after completion of the reaction as indicated in Figure 3 were subjected to amino acid analysis. In all cases, the amino acid composition deviated only from that of unmodified CPD-Y with respect to the methionine content which had decreased by approximately 0.5 residues after reaction with phenacylbromide, p-nitrophenacylbromide, and $\mathrm{m}$-nitrophenacylbromide. It is conceivable that the small decrease in the methionine content is due to a higher degree of regeneration of free methionine than with enzyme modified with iodoacetamide. Treatment of phenacylbromide modified CPD-Y with mercaptoethanol $(7 \mathrm{mM})$ caused an increase in the peptidase activity from $6 \%$ of the activity of unmodified CPD-Y to $85 \%$ within appromimately $1 \quad 1 / 2$ hours (Figure 4 ). This represents complete reactivation since mercaptoethanol even at the low concentration employed reduced the peptidase activity of unmodified CPD-Y to approximately $80 \%$ within $11 / 2$ hours (Figure 4). In the absence of mercaptoethanol the peptidase activity of the modified enzyme remained unchanged, demonstrating that mercaptoethanol, or possibly some other thiol, is needed for the reactivation. Thus, the changes in the activities of CPD-Y as a consequence of modification with phenacyl- 


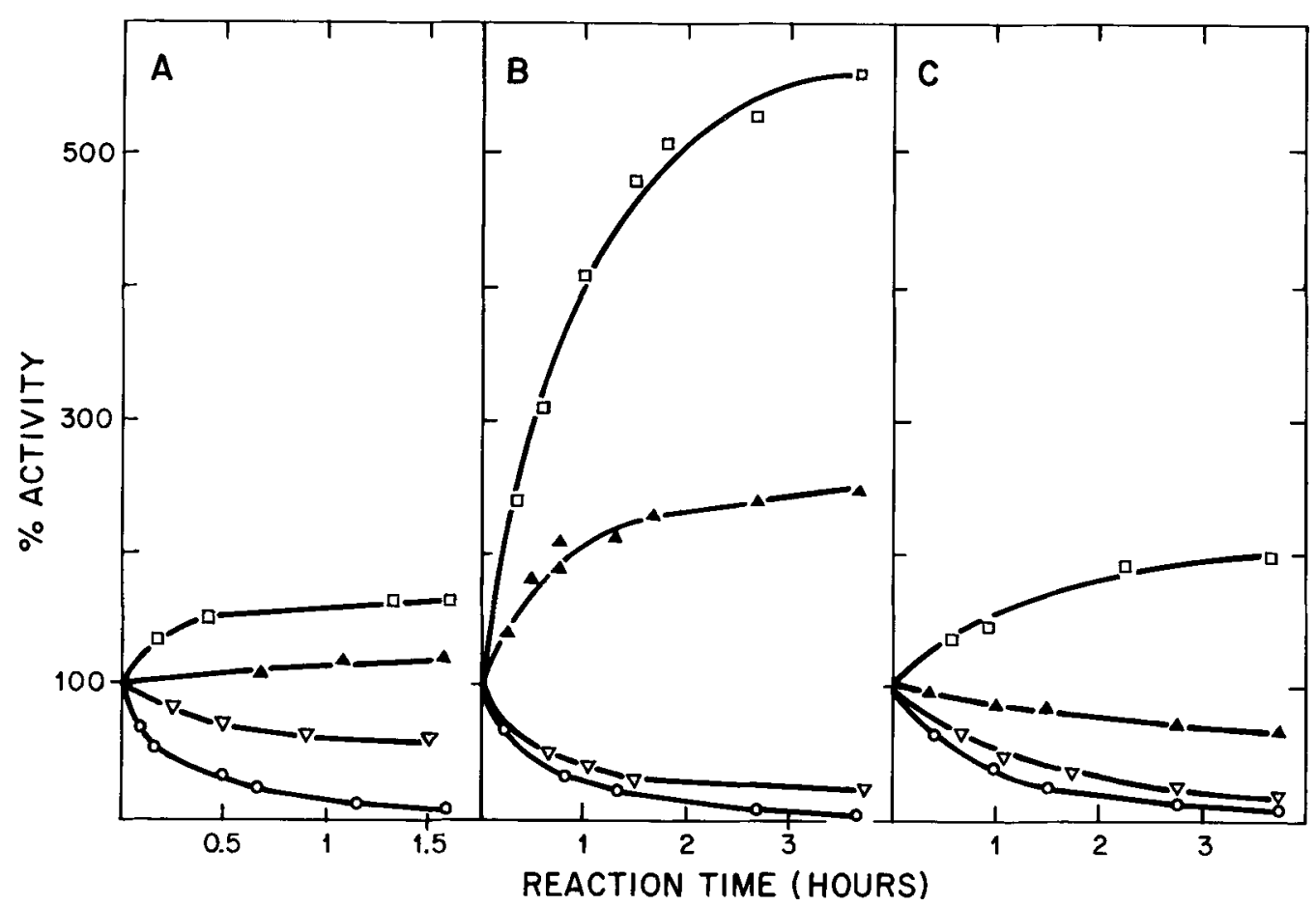

Figure 3. Modification of CPD-Y with phenacylbromide (Panel A), p-nitrophenacylbromide (Panel B) and m-nitrophenacylbromide (Panel C). Reaction conditions: $6.2 \mathrm{mg} / \mathrm{ml} \mathrm{CPD}-\mathrm{Y}, 0.03 \mathrm{M}-\mathrm{NaH}_{2} \mathrm{PO}_{4}, 0.12 \mathrm{M}-\mathrm{NaCl}$, $\mathrm{pH}$ 6.5. In addition, the reaction mixture contained: $2.5 \%$ methanol, $7.5 \mathrm{~mm}$-phenacylbromide (Panel $\mathrm{A}$ ); $9.0 \%$ methanol, 1.8 mM-p-nitrophenacylbromide (Panel B); 7.0\% methanol, 3.5 mM-m-nitrophenacylbromide (Panel C). The activities of the enzyme were assayed as described in Figure 2.

bromide can be attributed to alkylation of a methionyl residue as was observed with iodoacetamide.

\subsection{Affinity chromatography of CPD-Y derivatives}

The CPD-Y derivatives described in section 3.1 were separated from residual unmodified CPD-Y by affinity chromatography using CABS-Sepharose, a resin which previously has been employed in the purification of several other carboxypeptidases, including malt carboxypeptidase (8). At pH 4.8 CPD-Y as well as the alkylated derivatives described in section 3.1 were bound to this resin. However, the alkylated derivatives of CPD-Y could be eluted by including $0.5 \mathrm{M}-\mathrm{NaCl}$ in the buffer, thus increasing the ionic strength. The unmodified enzyme which remained bound to the column could subsequently be eluted by increasing $\mathrm{pH}$ to 7.5 (see section 2.2.3). Figure 5 shows the separation of CPD-Y modified with iodoacetamide (IAACPD-Y) from unmodified CPD-Y. It is observed that the modified enzyme eluting with $0.5 \mathrm{M}$ $\mathrm{NaCl}$ exhibited only very little peptidase activity towards FA-Phe-Leu-OH but significant esterase activity towards FA-Phe-OMe. In contrast, the enzyme eluting at $\mathrm{pH} 7.5$ exhibited high activity towards both substrates in accordance with the expectations for unmodified CPD-Y (see section 3.3) and hence, a separation of modified and unmodified enzyme had apparently been accomplished. Rechromatography of the modified enzyme eluted with $0.5 \mathrm{M}-\mathrm{NaCl}$ confirmed the absence of any unmodified enzyme in the preparation. The other preparations of modified enzyme obtained after treatment with phenacylbromide, p-nitrophenacylbromide, and $\mathrm{m}$-nitrophenacylbromide (section 3.1) were chromatographed on CABS-Sepharose in the same manner and similar elution profiles were observed. The affinity resin which 


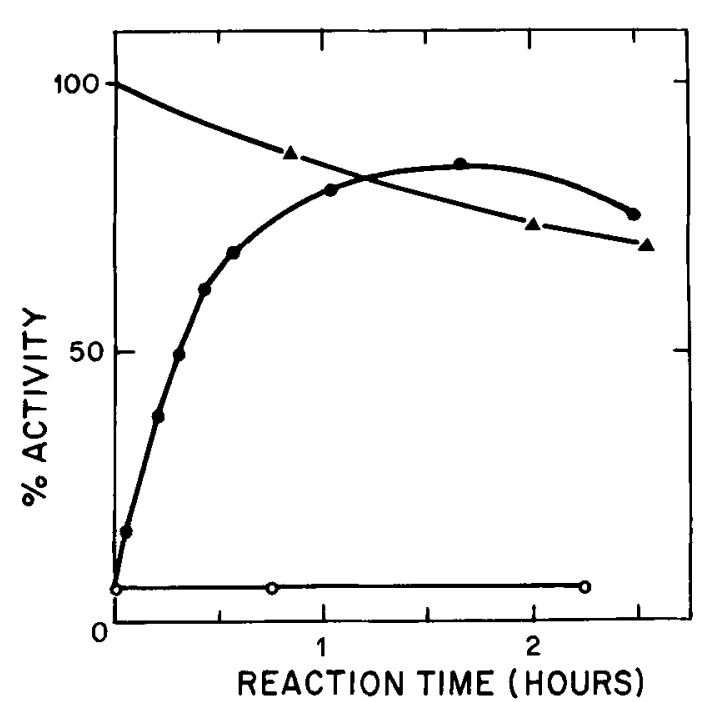

Figure 4. Thiolysis of CPD-Y treated with phenacylbromide. CPD-Y treated with phenacylbromide for 95 min (see Figure 3A) and then desalted by chromatography on Biogel P-4, equilibrated with water, was treated with mercaptoethanol using the following conditions: $0.17 \mathrm{mg} / \mathrm{ml}$ PAB-CPD-Y, $0.09 \mathrm{M}-\mathrm{NaH}_{2} \mathrm{PO}_{4}$, $7 \mathrm{~mm}$-2-mercaptoethanol, $\mathrm{pH} 7.5,25^{\circ} \mathrm{C}$. The activity of the enzyme towards FA-Phe ${ }^{\text {Leu-OH }}$ was assayed

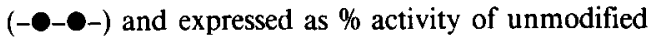
enzyme. The following control experiments were performed: $0.17 \mathrm{mg} / \mathrm{ml} \mathrm{PAB-CPD-Y,} 0.09 \mathrm{M}-\mathrm{NaH}_{2} \mathrm{PO}_{4}$, no mercaptoethanol, pH 7.5 (-O-O-), and 0.17 $\mathrm{mg} / \mathrm{ml}$ unmodified CPD-Y, $0.09 \mathrm{M}-\mathrm{NaH}_{2} \mathrm{PO}_{4}, 7 \mathrm{~mm}-$ mercaptoethanol, pH 7.5 (-А-\$-) .

originally was employed in purification of CPDY (18), i.e. p-aminobenzyl succinic acid coupled via an azo linkage to Sepharose-glycyl-L-tyrosine, failed to separate CPD-Y from its modified derivatives.

All the described derivatives of CPD-Y were stable at $25{ }^{\circ} \mathrm{C}$ within 5 hours at $\mathrm{pH} 5.0$ and 7.5 while at $\mathrm{pH} 9.0$ they were slowly inactivated in apparent first order reactions characterized by $t_{1 / 2}$ of about $11 / 2$ hours for IAA-CPD-Y and 4 hours for both PAB-CPD-Y, m-NPABCPD-Y and p-NPAB-CPD-Y. For unmodified CPD-Y t $1 / 2$ was 7 hours. At $\mathrm{pH} 10.0$ a further reduction in $t_{1} / 2$ was observed: 10 minutes for IAA-CPD-Y and 30 minutes for PAB-CPD-Y, m-NPAB-CPD-Y and p-NPAB-CPD-Y as compared with 60 minutes for unmodified CPD-Y. Thus, at $\mathrm{pH} 9.0$ and 10.0 the alkylated deriva- tives of CPD-Y were somewhat less stable than unmodified CPD-Y.

\subsection{Kinetic characterization of CPD-Y derivatives}

The alkylated derivatives of CPD-Y, isolated by affinity chromatography, i.e. IAA-CPD-Y, PAB-CPD-Y, p-NPAB-CPD-Y and m-NPABCPD-Y, were kinetically characterized using a series of FA-substrates which were selected such that they reflected the influence of the modifications on the leaving group specificity of the enzymes. It is apparent from the results listed in Table $I$ that modification of CPD-Y with iodoacetamide reduced $k_{\mathrm{ca}} / \mathrm{K}_{\mathrm{m}}$ for the hydrolysis of all ester substrates and this was due to both a reduction in $\mathrm{k}_{\mathrm{cat}}$ and an increase in $\mathbf{K}_{\mathrm{m}}$. Modification with phenacylbromide increased $\mathrm{k}_{\text {cat }} / \mathrm{K}_{\mathrm{m}}$ for the hydrolysis of FA-Phe-OMe and

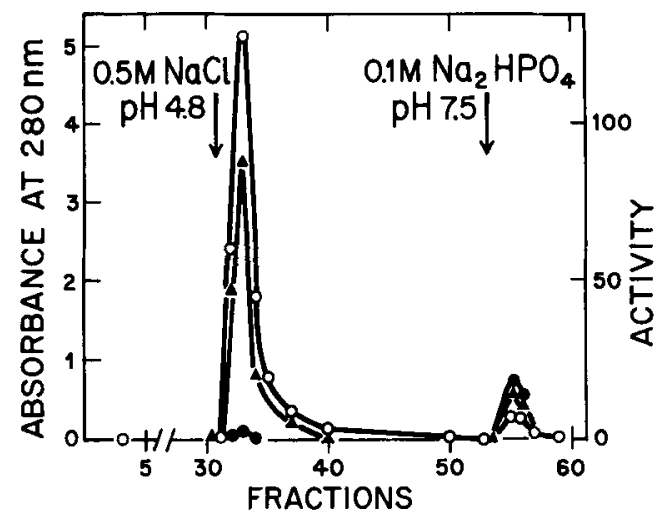

Figure 5. Affinity chromatography of CPD-Y modified with iodoacetamide. $40 \mathrm{mg}$ CPD-Y was reacted with iodoacetamide for four hours as described in Figure 2 and then desalted by chromatography on Biogel P-4, equilibrated with water. The preparation of modified enzyme was adjusted to $0.02 \mathrm{M}$-sodium acetate $\mathrm{pH}$ 4.8 and applied to a CABS-Sepharose affinity column $(1.6 \times 7.5 \mathrm{~cm}=15 \mathrm{ml})$, equilibrated with $0.02 \mathrm{M}$-sodium acetate $\mathrm{pH} 4.8$. The column was initially washed with the same buffer and the modified enzyme was then eluted with $0.02 \mathrm{M}$-sodium acetate, $0.5 \mathrm{M}-\mathrm{NaCl}$, pH 4.8. Unmodified CPD-Y was subsequently eluted with $0.1 \mathrm{M}-\mathrm{Na}_{2} \mathrm{HPO}_{4}, \mathrm{pH} 7.5$ The absorbance at 280 $\mathrm{nm}\left(-\mathrm{O}_{-} \mathrm{O}_{-}\right)$and the activities of the enzyme towards

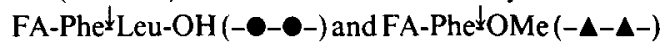
were measured. Fraction size: $3 \mathrm{ml}$, flow-rate: 90 $\mathrm{ml} \cdot$ hour $^{-1}$. 
Table I.

Kinetic parameters for the hydrolysis of ester substrates by CPD-Y, IAA-CPD-Y, PAB-CPD-Y, m-NPAB-CPD-Y, and p-NPAB-CPD-Y.

\begin{tabular}{|c|c|c|c|c|c|}
\hline Substrate & Enzyme & $\begin{array}{l}\text { Substrate range } \\
\text { (mM) }\end{array}$ & $\begin{array}{l}k_{\text {cat }} \\
\left(\min ^{-1}\right)\end{array}$ & $\begin{array}{l}\mathbf{K}_{\mathrm{m}} \\
(\mathrm{mM})\end{array}$ & $\begin{array}{l}k_{\mathrm{ca} /} / \mathrm{K}_{\mathrm{m}} \\
\left(\mathrm{min}^{-1} \cdot \mathrm{mM}^{-1}\right)\end{array}$ \\
\hline \multirow{5}{*}{ FA-Phe-OMe } & CPD-Y & $0.25-1.0$ & 11000 & 0.39 & 28000 \\
\hline & IAA-CPD-Y & $0.2-1.0$ & 6300 & 0.87 & 7200 \\
\hline & PAB-CPD-Y & $0.05-0.4$ & 6400 & 0.078 & 82000 \\
\hline & p-NPAB-CPD-Y & $0.05-0.5$ & 22000 & 0.48 & 46000 \\
\hline & m-NPAB-CPD-Y & $0.05-0.5$ & 5200 & 0.23 & 23000 \\
\hline \multirow{5}{*}{ FA-Leu-OMe } & CPD-Y & $\begin{array}{ll}0.2 & -2.0\end{array}$ & 4000 & 0.36 & 11100 \\
\hline & IAA-CPD-Y & $0.2-1.5$ & 2000 & 0.34 & 5900 \\
\hline & PAB-CPD-Y & $0.02-0.1$ & 2300 & 0.041 & 56000 \\
\hline & p-NPAB-CPD-Y & $0.05-0.5$ & 3800 & 0.33 & 11500 \\
\hline & m-NPAB-CPD-Y & $0.05 \quad-0.5$ & 1500 & 0.14 & 10700 \\
\hline \multirow{5}{*}{ FA-Phe-OEt } & CPD-Y & $0.025-0.25$ & 11000 & 0.059 & 190000 \\
\hline & IAA-CPD-Y & $0.025-0.3$ & 8200 & 0.10 & 82000 \\
\hline & PAB-CPD-Y & $0.02-0.12$ & 4500 & 0.11 & 41000 \\
\hline & p-NPAB-CPD-Y & $0.05-0.5$ & 17000 & 0.26 & 66000 \\
\hline & m-NPAB-CPD-Y & $\begin{array}{lll}0.05 & -0.5\end{array}$ & 6400 & 0.20 & 32000 \\
\hline \multirow{5}{*}{ FA-Ala-OEt } & CPD-Y & $0.4 \quad-3.3$ & 4600 & 1.0 & 4600 \\
\hline & IAA-CPD-Y & $\begin{array}{ll}0.4 & -3.3\end{array}$ & 4100 & 1.3 & 3200 \\
\hline & PAB-CPD-Y & $\begin{array}{ll}0.4 & -3.3\end{array}$ & 4400 & 2.0 & 2200 \\
\hline & p-NPAB-CPD-Y & $\begin{array}{ll}0.5 & -5.0\end{array}$ & 30000 & 14 & 2100 \\
\hline & m-NPAB-CPD-Y & $\begin{array}{ll}0.5 & -5.0\end{array}$ & 6000 & 2.0 & 3000 \\
\hline \multirow{5}{*}{ FA-Ala-OBzl } & CPD-Y & $0.025-0.25$ & 9100 & 0.054 & 170000 \\
\hline & IAA-CPD-Y & $0.07-0.5$ & 3300 & 0.36 & 9700 \\
\hline & PAB-CPD-Y & $0.1-0.5$ & 680 & 0.43 & 1600 \\
\hline & p-NPAB-CPD-Y & $\begin{array}{ll}0.05 & -0.5\end{array}$ & 940 & 0.48 & 2000 \\
\hline & m-NPAB-CPD-Y & $0.05-0.5$ & 620 & 0.45 & 1380 \\
\hline
\end{tabular}

The rates of hydrolysis were determined spectrophotometrically at $329-358 \mathrm{~nm}$. Assays were performed in 0.05 M-Hepes, I mM-EDTA, $2.5 \%$ methanol, $\mathrm{pH} 7.5,25^{\circ} \mathrm{C}$.

FA-Leu-OMe, while a decrease was observed for ester substrates with larger leaving groups. For all the ester substrates tested $k_{\text {cat }}$ was reduced while $K_{m}$ varied in both directions: it decreased for FA-Phe-OMe and FA-Leu-OMe and increased for the other substrates in Table $I$. Modification with p-nitrophenacylbromide similarly increased $k_{c a} / K_{m}$ for the hydrolysis of FA-Phe-OMe and FA-Leu-OMe, and reduced $\mathbf{k}_{\text {cat }} / \mathrm{K}_{\mathrm{m}}$ for the other ester substrates tested. $\mathrm{K}_{\mathrm{m}}$ increased for the hydrolysis of all the ester substrates investigated except FA-Leu-OMe which remained essentially unchanged while $\mathrm{k}_{\mathrm{cat}}$ varied in both directions: with FA-Phe-OMe, FA-Leu-OMe, FA-Phe-OEt, and FA-Ala-OEt it increased while it decreased with FA-Ala-OBzl. Modification of CPD-Y with $m$-nitrophenacylbromide caused a decrease in $k_{\text {cat }} / K_{m}$ for the hydrolysis of all the tested ester substrates except FA-Leu-OMe for which it remained essentially unchanged. $k_{\text {cat }}$ increased slightly for FAAla-OEt and decreased for all the other ester substrates tested. $K_{m}$ decreased for FA-Phe $\_$OMe and FA-Leu-OMe and increased for the other substrates.

Thus, all the described alkylations of a methionyl residue in CPD- $Y$ caused a drastic reduction in $\mathrm{k}_{\mathrm{ca}} / \mathrm{K}_{\mathrm{m}}$ for the hydrolysis of FA-Ala-OBzl which contains a bulky leaving group. $\mathrm{k}_{\mathrm{ca}} / \mathrm{K}_{\mathrm{m}}$ for the hydrolysis of ester substrates with rela- 
Table II.

$k_{\text {cat }} / K_{\mathbf{m}}$ for the CPD-Y, IAA-CPD-Y, PAB-CPD-Y, m-NPAB-CPD-Y and p-NPAB-CPD-Y catalyzed release of ammonia and amino acid amides from peptide amides.

\begin{tabular}{|c|c|c|}
\hline Substrate & Enzyme & $\begin{array}{l}\mathbf{k}_{\mathrm{ca}} / \mathrm{K}_{\mathrm{m}} \\
\left(\mathrm{min}^{-1} \cdot \mathrm{mM}^{-1}\right)\end{array}$ \\
\hline \multirow{5}{*}{$\mathrm{FA}-\mathrm{Val}-\mathrm{NH}_{2}$} & CPD-Y & 0.95 \\
\hline & IAA-CPD-Y & 0.48 \\
\hline & PAB-CPD-Y & 1.7 \\
\hline & p-NPAB-CPD-Y & 2.7 \\
\hline & m-NPAB-CPD-Y & 2.3 \\
\hline \multirow{5}{*}{ FA-Leu- ${ }^{\downarrow} \mathrm{NH}_{2}$} & CPD-Y & 52 \\
\hline & IAA-CPD-Y & 14 \\
\hline & PAB-CPD-Y & 160 \\
\hline & p-NPAB-CPD-Y & 73 \\
\hline & m-NPAB-CPD-Y & 120 \\
\hline \multirow{5}{*}{$\mathrm{FA}-\mathrm{Phe}-\mathrm{NH}_{2}$} & CPD.Y & 89 \\
\hline & IAA-CPD-Y & 17 \\
\hline & PAB-CPD-Y & 220 \\
\hline & p-NPAB-CPD-Y & 450 \\
\hline & m-NPAB-CPD-Y & 200 \\
\hline \multirow{5}{*}{ FA-Phe-Gly-NH ${ }_{2}$} & CPD $-Y$ & 160 \\
\hline & IAA-CPD-Y & 21 \\
\hline & PAB-CPD-Y & 78 \\
\hline & p-NPAB-CPD-Y & 17 \\
\hline & m-NPAB-CPD-Y & 18 \\
\hline \multirow{5}{*}{ FA-Phe-Val-NH ${ }_{2}$} & CPD-Y & 6200 \\
\hline & IAA-CPD-Y & 360 \\
\hline & PAB-CPD-Y & 71 \\
\hline & p-NPAB-CPD-Y & 110 \\
\hline & m-NPAB-CPD-Y & 100 \\
\hline
\end{tabular}

The rates of hydrolysis were determined spectrophotometrically at $329-337 \mathrm{~nm}$. Assays were performed with 0.5 mM-substrate in 0.05 M-Hepes, I mM-EDTA, 2.5\% methanol, pH 7.5, $25^{\circ} \mathrm{C}$, with the exception of FAPhe-Val- $\mathrm{NH}_{2}$ where methanol was replaced with DMF and the substrate concentration only $0.1 \mathrm{~mm}$.

tively small leaving groups, i.e. FA-Phe-OMe, FA-Leu-OMe, FA-Phe $\downarrow$ OEt, and FA-Ala-OEt were much less affected by these modifications. It was of interest that with PAB-CPD-Y and p-NPAB-CPD-Y $k_{\mathrm{ca}} / \mathrm{K}_{\mathrm{m}}$ for the hydrolysis of FA-Leu-OMe and FA-Phe-OMe was even higher than with CPD-Y.

A similar dependence of the effects of alkylation on the size of the leaving group was observed with peptide amide substrates (Table II). With PAB-CPD-Y, m-NPAB-CPD-Y and p-NPAB$C P D-Y k_{\text {cal }} / K_{m}$ for the release of ammonia from FA-Val- $\mathrm{NH}_{2}$, FA-Phe- $\mathrm{NH}_{2}$ and FA-Leu- $\mathrm{NH}_{2}$ were significantly higher than with unmodified CPD- $Y$ while $k_{c a t} / K_{m}$ for the release of the amino acid amide from FA-Phe-Gly- $\mathrm{NH}_{2}$ and especially FA-Phe-Val- $\mathrm{NH}_{2}$ were significantly lower than with unmodified CPD-Y. IAA-CPD-Y behaves differently since a decrease in $k_{\mathrm{cal}} / \mathrm{K}_{\mathrm{m}}$ was observed for the hydrolysis of all the substrates listed in Table II. However, the decrease was most pronounced for the substrate with the bulkiest leaving group, i.e. FA-Phe`Val- $\mathrm{NH}_{2}$.

The ability of CPD-Y to hydrolyse peptides with unblocked carboxyl groups was affected by all the modifications listed in section 3.1 in a manner which was only slightly dependent on the bulkiness of the leaving group of the substrate (Table III). Modification of CPD-Y with iodoacetamide caused a drastic decrease in $\mathrm{k}_{\mathrm{cat}}$ and a relatively small increase in $\mathrm{K}_{\mathrm{m}}$ for the hydrolysis of all the peptide substrates listed in Table III. Modification of CPD-Y with phenacylbromide, p-nitrophenacylbromide and $\mathrm{m}$ nitrophenacylbromide had a similar influence on the kinetic parameters with the exception that the PAB-CPD-Y catalyzed hydrolysis of FA-Phe $-\mathrm{Gly}-\mathrm{OH}$ was characterized by a $\mathrm{K}_{\mathrm{m}}$ which was reduced relative to that observed with unmodified CPD-Y.

The influence of $\mathrm{pH}$ on the kinetic parameters for the CPD-Y and PAB-CPD-Y catalyzed hydrolysis of FA-Phe-Ala-OH is shown in Figure 6. With CPD-Y (Panel A) it was observed that $\mathrm{k}_{\text {cat }}$ is dependent on an ionizable group with a $\mathrm{pK}_{\mathrm{a}}$ of 5.5-6.0 while $\mathrm{K}_{\mathrm{m}}$ is dependent on a group with $\mathrm{pK}_{\mathrm{a}}>$ 7.5. With PAB-CPD-Y (Panel B) the $K_{m}$ value determined at each $\mathrm{pH}$ value varied only slightly from that obtained with unmodified CPD- $Y$ while the low $k_{\text {cat }}$ values observed with PAB-CPD-Y at all $\mathrm{pH}$ values rendered these determinations less accurate.

\subsection{Applications of alkylated CPD-Y de- rivatives in deamidation reactions}

The action of CPD-Y on a peptide amide $\mathrm{X}-\mathrm{A}-\mathrm{B}-\mathrm{NH}_{2}$ where $\mathrm{A}$ and $\mathrm{B}$ are amino acid residues and $\mathrm{X}$ an $\mathrm{N}$-blocking group results in 
Table III. Kinetic parameters for the hydrolysis of peptide substrates by CPD-Y, IAA-CPD-Y, PAB-CPD-Y, m-NPAB-CPD-Y, and p-NPAB-CPD-Y.

\begin{tabular}{|c|c|c|c|c|c|}
\hline Substrate & Enzyme & $\begin{array}{l}\text { Substrate range } \\
(\mathrm{mM})\end{array}$ & $\begin{array}{l}\mathrm{k}_{\text {cat }} \\
\left(\min ^{-1}\right)\end{array}$ & $\begin{array}{l}\mathrm{K}_{\mathrm{m}} \\
(\mathrm{mM})\end{array}$ & $\begin{array}{l}\mathrm{k}_{\mathrm{cat}} / \mathrm{K}_{\mathrm{m}} \\
\left(\mathrm{min}^{-1} \cdot \mathrm{mM}^{-1}\right)\end{array}$ \\
\hline \multirow{5}{*}{ FA-Phe-Gly-OH } & CPD-Y & -15 & 5800 & 5.4 & 1100 \\
\hline & IAA-CPD-Y & -15 & 190 & 8.7 & 22 \\
\hline & PAB-CPD-Y & $0.8-3$ & 180 & 1.6 & 110 \\
\hline & p-NPAB-CPD-Y & $0.5-5$ & 240 & 13 & 18 \\
\hline & m-NPAB-CPD-Y & $1 \quad-10$ & 110 & 7.7 & 14 \\
\hline \multirow{5}{*}{ FA-Phe-Ala-OH } & CPD-Y & $0.15-1.5$ & 9700 & 0.14 & 61000 \\
\hline & IAA-CPD-Y & $0.15-1.5$ & 390 & 0.71 & 550 \\
\hline & PAB-CPD-Y & $0.15-1.5$ & 260 & 0.42 & 620 \\
\hline & p-NPAB-CPD-Y & $0.1-1.0$ & 360 & 0.45 & 800 \\
\hline & m-NPAB-CPD-Y & $0.1-1.0$ & 150 & 0.45 & 330 \\
\hline \multirow{5}{*}{ FA-Phe-Val-OH } & CPD-Y & $0.025-0.25$ & 6500 & 0.047 & 140000 \\
\hline & IAA-CPD-Y & $0.025-0.25$ & 140 & 0.13 & 1100 \\
\hline & PAB-CPD-Y & $0.025-0.25$ & 92 & 0.080 & 1200 \\
\hline & p-NPAB-CPD-Y & $0.025-0.25$ & 150 & 0.076 & 2000 \\
\hline & m-NPAB-CPD-Y & $0.025-0.25$ & 103 & 0.060 & 1700 \\
\hline \multirow{5}{*}{ FA-Phe-Leu-OH } & CPD-Y & $0.01-0.1$ & 4900 & 0.021 & 230000 \\
\hline & IAA-CPD-Y & $0.025-0.1$ & 25 & 0.080 & 320 \\
\hline & PAB-CPD-Y & $0.025-0.2$ & 41 & 0.033 & 1200 \\
\hline & p-NPAB-CPD-Y & $0.02-0.1$ & 61 & 0.029 & 2100 \\
\hline & m-NPAB-CPD-Y & $0.02-0.1$ & 41 & 0.032 & 1300 \\
\hline
\end{tabular}

The rates of hydrolysis were determined spectrophotometrically at $329-358 \mathrm{~nm}$. Assays were performed in 0.05 M-Mes, 1 mM-EDTA, pH $6.5,25^{\circ} \mathrm{C}$.

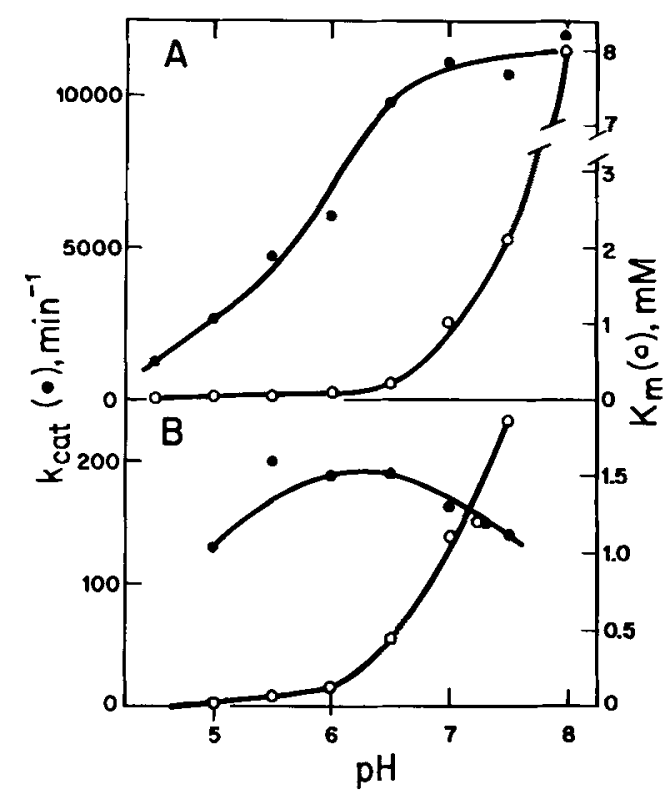

Figure 6. The influence of $\mathrm{pH}$ on the kinetic parameters for the CPD-Y (Panel A) and PAB-CPD-Y (Panel B) catalyzed hydrolysis of FA-Phe ${ }^{\ddagger}$ Ala-OH. The assays were performed in $0.05 \mathrm{M}$-Mes, $1 \mathrm{mM}$-EDTA in the $\mathrm{pH}$ range $4.5-6.5$ and in $0.05 \mathrm{M}$-Hepes, 1 mM-EDTA in the $\mathrm{pH}$ range $7.0-8.0$.

the formation of two products: X-A-B-OH, formed via the amidase activity of the enzyme by release of $\mathrm{NH}_{3}$ (Scheme 2, Reaction I), and $\mathrm{X}-\mathrm{A}-\mathrm{OH}$. The latter product arise either due to the peptidyl amino acid amide hydrolase activity of CPD-Y by direct release of $\mathrm{H}-\mathrm{B}-\mathrm{NH}_{2}$ (Scheme 2, Reaction II), or by secondary release of $\mathrm{H}-\mathrm{B}-\mathrm{OH}$ from X-A-B-OH due to the peptidase activity of the enzyme (Scheme 2, Reaction III). At $\mathrm{pH} 10.0$ CPD-Y exhibits negligible 


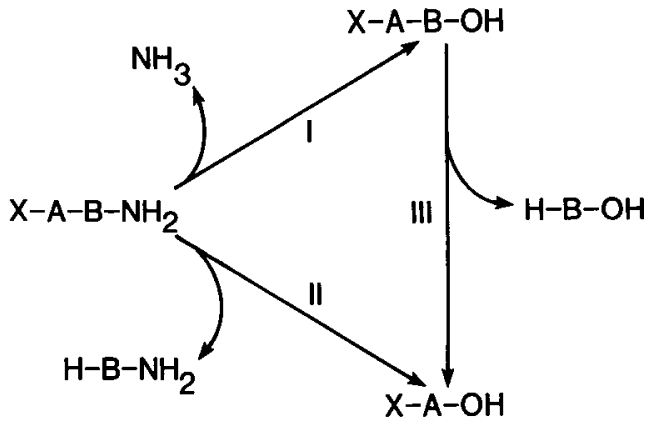

Scheme 2. CPD-Y catalyzed deamidation reactions. Reactions I, II, and III represent amidase, peptidyl amino acid amide hydrolase and peptidase activities, respectively. $X=\mathrm{N}$-blocking group, $\mathrm{A}$ and $\mathrm{B}=$ amino acid residues.

peptidase activity such that the rate of Reaction III is very low relative to the rates Reactions I and II (4). Using these conditions a series of $\mathrm{N}$-blocked dipeptide amides were subjected to CPD-Y catalyzed deamidation in order to estab- lish the influence of the C-terminal sequence of the peptide amides on the yield of X-A-B-OH, i.e. the yield of deamidation. It is apparent (Table IV) that the nature of $\mathrm{X}$ has only a minor influence on the yield of deamidation since essentially identical yields were obtained with FA-Phe-Gly- $\mathrm{NH}_{2}$ and Z-Phe-Gly- $\mathrm{NH}_{2}$ as well as with $\mathrm{Bz}-\mathrm{Ala}-\mathrm{Ala}-\mathrm{NH}_{2}$ and Z-Ala-Ala- $\mathrm{NH}_{2}$. In contrast, the nature of $A$ has a pronounced influence on the yield of deamidation, e.g. ZAla-Ala- $\mathrm{NH}_{2}$ and Z-Gly-Ala- $\mathrm{NH}_{2}$ deamidate in yields of $31 \%$ and $100 \%$, respectively. An influence of the nature of $B$ is also observed, e.g. Z-Ala-Gly- $\mathrm{NH}_{2}$ and Z-Ala-Phe- $\mathrm{NH}_{2}$ deamidate in yields of $2 \%$ and $60 \%$, respectively.

Relative to CPD-Y, PAB-CPD-Y is characterized by high amidase activity and low peptidyl amino acid amide hydrolase and peptidase activities (see section 3.3) and consequently, one might expect this enzyme to catalyze Reaction I in Scheme 2 more specifically than CPD-Y with higher yields of deamidation as a result.

Table IV.

CPD-Y catalyzed deamidation reactions. The influence of the substrate structure.

\begin{tabular}{|c|c|c|c|c|c|c|}
\hline \multirow{2}{*}{$\begin{array}{l}\text { Substrate } \\
\left(\mathrm{X}-\mathrm{A}-\mathrm{B}-\mathrm{NH}_{2}\right)\end{array}$} & \multirow{2}{*}{$\begin{array}{l}\text { CPD-Y } \\
(\mu \mathrm{M})\end{array}$} & \multirow{2}{*}{$\begin{array}{l}\text { Reaction } \\
\text { time } \\
(\mathrm{min})\end{array}$} & \multicolumn{3}{|c|}{ Reactant composition } & \multirow{2}{*}{$\begin{array}{l}\text { Yield of } \\
\text { X-A-B-OH } \\
(\%)\end{array}$} \\
\hline & & & $\begin{array}{c}\text { X-A-B-OH } \\
\text { (\%) }\end{array}$ & $\begin{array}{c}\mathrm{X}-\mathrm{A}-\mathrm{OH} \\
(\%)\end{array}$ & $\begin{array}{c}\text { X-A-B-NH } \\
(\%)\end{array}$ & \\
\hline Z-Ala-Gly-NH ${ }_{2}$ & 62 & 34 & 2 & 92 & 6 & 2 \\
\hline Z-Phe-Gly-NH ${ }_{2}$ & 18 & 5 & 0 & 84 & 16 & 0 \\
\hline FA-Phe-Gly-NH ${ }_{2}$ & 3.9 & 25 & 4 & 88 & 8 & 4 \\
\hline Z-Val-Gly-NH ${ }_{2}$ & 62 & 25 & 42 & 49 & 9 & 46 \\
\hline Z-Ala-Ser-NH ${ }_{2}$ & 31 & 35 & 0 & 70 & 30 & 0 \\
\hline Z-Gly-Ala- $\mathrm{NH}_{2}$ & 36 & 30 & 65 & 0 & 35 & 100 \\
\hline Z-Ile-Ala-NH ${ }_{2}$ & 18 & 5 & 94 & 6 & 0 & 94 \\
\hline Z-Val-Ala-NH ${ }_{2}$ & 18 & 30 & 94 & 6 & 0 & 94 \\
\hline Z-Ala-Ala- $\mathrm{NH}_{2}$ & 7.8 & 12 & 24 & 54 & 23 & 31 \\
\hline Bz-Ala-Ala- $\mathrm{NH}_{2}$ & 7.8 & 30 & 31 & 67 & 2 & 31 \\
\hline Bz-Ala-Thr- $\mathrm{NH}_{2}$ & 15 & 63 & 8 & 78 & 14 & 9 \\
\hline Bz-Phe-Gln-NH ${ }_{2}$ & 15 & 16 & 11 & 89 & 0 & 11 \\
\hline Bz-Arg-Phe-Val-NH & 21.6 & 15 & 58 & 30 & 12 & 66 \\
\hline Bz-Ala-Val-NH & 16 & 18 & 9 & 79 & 12 & 10 \\
\hline Bz-Ala-Ile-NH ${ }_{2}$ & 23 & 20 & 10 & 89 & 1 & 10 \\
\hline Bz-Ala-Leu- $\mathrm{NH}_{2}$ & 3.1 & 22 & 60 & 38 & 2 & 60 \\
\hline Bz-Phe-His- $\mathrm{NH}_{2}$ & 16 & 18 & 28 & 72 & 0 & 28 \\
\hline Bz-Ala-Phe-NH ${ }_{2}$ & 2.4 & 20 & 66 & 34 & 0 & 66 \\
\hline Z-Ala-Met-NH ${ }_{2}$ & 4.7 & 20 & 36 & 64 & 0 & 36 \\
\hline
\end{tabular}

Reaction conditions: 2 mM-substrate, 1 mM-EDTA, 10\% DMF, pH 10.0, $22{ }^{\circ} \mathrm{C}$. The reactant composition was determined by HPLC. 


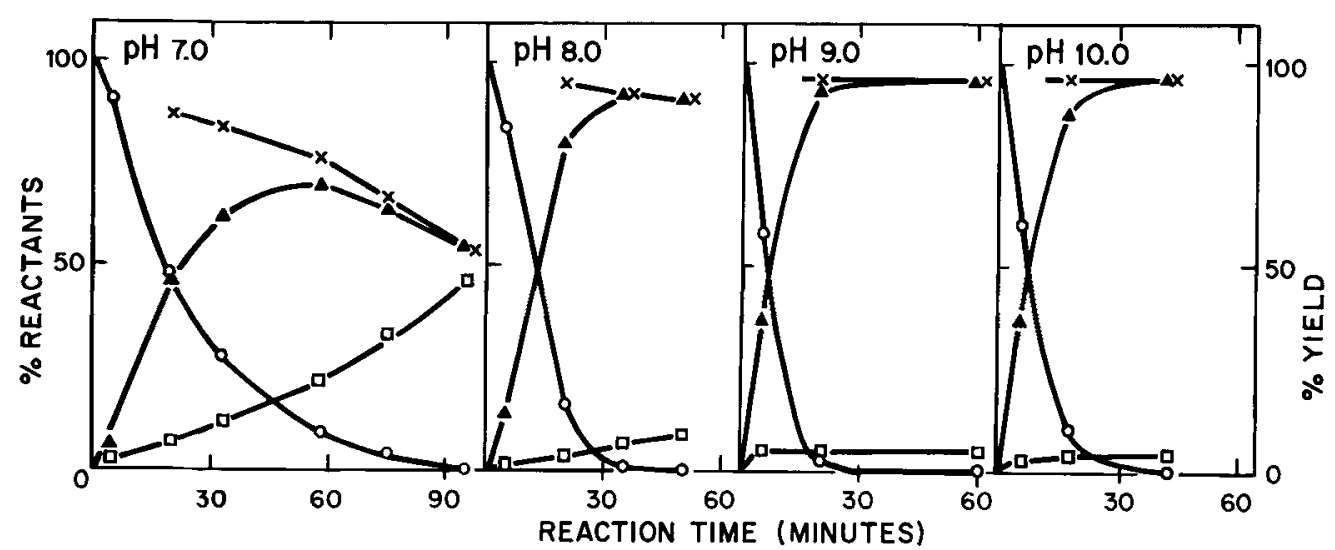

Figure 7. Deamidation of Bz-Ala-Phe- $\mathrm{NH}_{2}$ with phenacylbromide modified CPD-Y (PAB-CPD-Y). Reaction conditions: 5 mM-Bz-Ala-Phe-NH ${ }_{2}, 1$ mM-EDTA, 10\% DMF, $3.9 \mu$ M-PAB-CPD-Y. -O-O- Bz-Ala-Phe-NH $\mathrm{NH}_{2}$; $-\square-\square-$ Bz-Ala-OH; -A-A- Bz-Ala-Phe-OH. $-x-x-$ yield of deamidation, i.e. Bz-Ala-Phe-OH/(Bz-Ala-OH + Bz-Ala-Phe-OH).

Since the amidase activity of CPD-Y is known to remain constant at $\mathrm{pH}$ values higher than 7.0 whereas the peptidase activity decreases with $\mathrm{pH}(8,15)$ the influence of $\mathrm{pH}$ on PAB-CPD-Y catalyzed deamidation reactions was investigated. As shown in Figure 7, in deamidation of Bz-Ala-Phe- $\mathrm{NH}_{2}$ at $\mathrm{pH} 7.0$ the yield of Bz-Ala-
Phe-OH decreased significantly with the extent of the reaction, suggesting that $\mathrm{Bz}-\mathrm{Ala}-\mathrm{OH}$ at this $\mathrm{pH}$ is formed not only via Reaction II but also via Reaction III (Scheme 2). Increasing pH to 8.0 reduced the rate of this undesired reaction III since the yield of Bz-Ala-Phe-OH only decreased slightly during the course of the deami-

Table V.

PAB-CPD-Y catalyzed deamidation reactions. The influence of the substrate structure.

\begin{tabular}{|c|c|c|c|c|c|c|}
\hline \multirow{2}{*}{$\begin{array}{l}\text { Substrate } \\
\left(\mathrm{X}-\mathrm{A}-\mathrm{B}-\mathrm{NH}_{2}\right)\end{array}$} & \multirow{2}{*}{$\begin{array}{l}\text { PAB-CPD-Y } \\
(\mu \mathrm{M})\end{array}$} & \multirow{2}{*}{$\begin{array}{l}\text { Reaction } \\
\text { time } \\
(\mathrm{min})\end{array}$} & \multicolumn{3}{|c|}{ Reactant composition } & \multirow{2}{*}{$\begin{array}{c}\text { Yield of } \\
\text { X-A-B-OH } \\
(\%)\end{array}$} \\
\hline & & & $\begin{array}{c}\text { X-A-B-OH } \\
(\%)\end{array}$ & $\begin{array}{c}\text { X-A-OH } \\
(\%)\end{array}$ & $\begin{array}{c}\mathrm{X}-\mathrm{A}-\mathrm{B}-\mathrm{NH}_{2} \\
(\%)\end{array}$ & \\
\hline Z-Ala-Gly-NH & 16 & 180 & 8 & 72 & 20 & 10 \\
\hline FA-Phe-Gly-NH & 16 & 17 & 21 & 77 & 2 & 21 \\
\hline Z-Val-Gly-NH & 16 & 43 & 43 & 45 & 12 & 49 \\
\hline Z-Ala-Ser-NH ${ }_{2}$ & 16 & 155 & 27 & 50 & 23 & 35 \\
\hline Z-Ala-Ala-NH & 2.9 & 28 & 83 & 2 & 15 & 98 \\
\hline Bz-Ala-Ala- $\mathrm{NH}_{2}$ & 9.2 & 30 & 96 & 0 & 4 & 100 \\
\hline Bz-Ala-Thr- $\mathrm{NH}_{2}$ & 16 & 170 & 72 & 13 & 15 & 85 \\
\hline Bz-Phe-Gln-NH & 12 & 80 & 81 & 19 & 0 & 81 \\
\hline Bz-Ala-Val-NH ${ }_{2}$ & 17 & 50 & 87 & 4 & 9 & 96 \\
\hline Bz-Arg-Phe-Val-NH ${ }_{2}$ & 9.3 & 12 & 96 & 4 & 0 & 96 \\
\hline Bz-Ala-Ile- $\mathrm{NH}_{2}$ & 16 & 28 & 82 & 7 & 11 & 92 \\
\hline Bz-Ala-Leu-NH ${ }_{2}$ & 3.9 & 12 & 97 & 2 & 1 & 98 \\
\hline Bz-Phe-His- $\mathrm{NH}_{2}$ & 9.8 & 25 & 92 & 8 & 0 & 92 \\
\hline Bz-Ala-Phe- $\mathrm{NH}_{2}$ & 3.9 & 20 & 93 & 4 & 3 & 96 \\
\hline Z-Ala-Met-NH & 4.9 & 7 & 90 & 0 & 10 & 100 \\
\hline
\end{tabular}

Reaction conditions: 2 mM-substrate, 1 mM-EDTA, 10\% DMF, pH 9.0, $22{ }^{\circ} \mathrm{C}$. The reactant composition was determined by HPLC. 


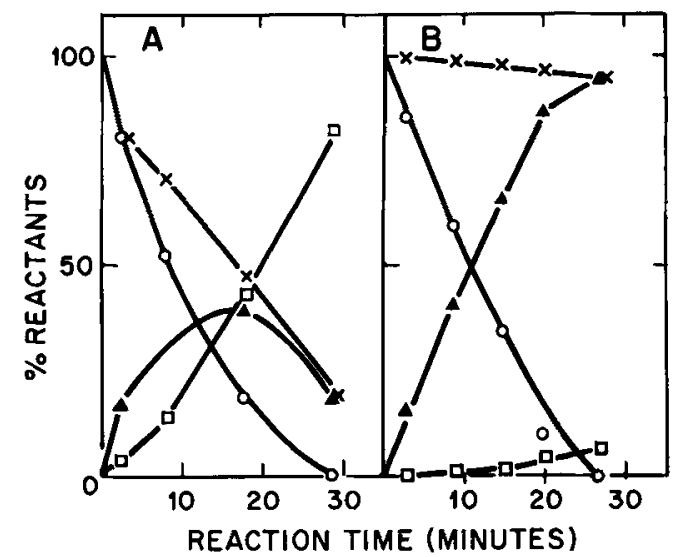

Figure 8. The action of CPD-Y (Panel A) and PABCPD-Y (Panel B) on Z-Ala-Ile-OMe. Reaction conditions: $2 \mathrm{~mm}$-Z-Ala-Ile-OMe, $1 \mathrm{~mm}$-EDTA, $0.23 \mu \mathrm{M}$ CPD-Y or $0.71 \mu \mathrm{M}$-PAB-CPD-Y, pH 7.5. Z-Ala-Ile$\mathrm{OMe},-\mathrm{O}-\mathrm{O}-$; Z-Ala-OH, - $\square-\square-;$ Z-Ala-Ile-OH, $-\Delta-\Delta-$; yield of Z-Ala-Ile-OH, $-x-x-$.

dation reaction. At pH 9.0 the yield of Bz-AlaPhe-OH remained constant during the reaction suggesting that the rate of reaction III was negligible compared to the rates of Reactions I and II. A further increase in pH from 9.0 to 10.0 had no beneficial effects and consequently, all further deamidation reactions with PABCPD. $Y$ were performed at $\mathrm{pH} 9.0$ since the enzyme is more stable at this $\mathrm{pH}$ than at $\mathrm{pH}$ 10.0 (see section 3.2).
A series of $\mathrm{N}$-blocked dipeptide amides were deamidated with PAB-CPD-Y in yields of 85 $100 \%$ with the exception of those with C-terminal seryl or glycyl residues which were deamidated in significantly lower yields (10-49\%) (Table V). A comparison of Tables IV and V show that the yields generally are higher with PABCPD-Y than those obtained with unmodified CPD-Y, the increase being most pronounced for peptide amides with C-terminal Ala, His, Val, Ile and Thr, while only slightly higher yields are observed for peptide amides with C-terminal Ser and Gly. The modification of CPD-Y with phenacylbromide thus increased the ratio of amidase to peptidyl amino acid amide hydrolase activities essentially irrespective of the C-terminal sequence.

The other alkylated derivatives of CPD-Y described in section 3.1, i.e. IAA-CPD-Y, pNPAB-CPD-Y and m-NPAB-CPD-Y, were similarly tested as deamidases. With Bz-AlaPhe- $\mathrm{NH}_{2}$, Bz-Ala-Val- $\mathrm{NH}_{2}, \quad$ Bz-Phe-His- $\mathrm{NH}_{2}$, Bz-Ala-Thr- $\mathrm{NH}_{2}$, Z-Ala-Ala- $\mathrm{NH}_{2}$, and Z-AlaMet- $\mathrm{NH}_{2}$ as substrates it was found that the yields of deamidation using IAA-CPD-Y were identical or lower than observed with unmodified CPD-Y. With m-NPAB-CPD-Y and pNPAB-CPD-Y the yields of deamidation were higher than with CPD-Y but in general slightly lower than with PAB-CPD-Y, e.g. the yields of deamidation of Z-Ala-Ala- $\mathrm{NH}_{2}$ were $98 \%, 85 \%$, $81 \%, 20 \%$, and $31 \%$ using PAB-CPD-Y, p-

Table VI.

CPD-Y and PAB-CPD-Y catalyzed removal of ester groups from peptide esters.

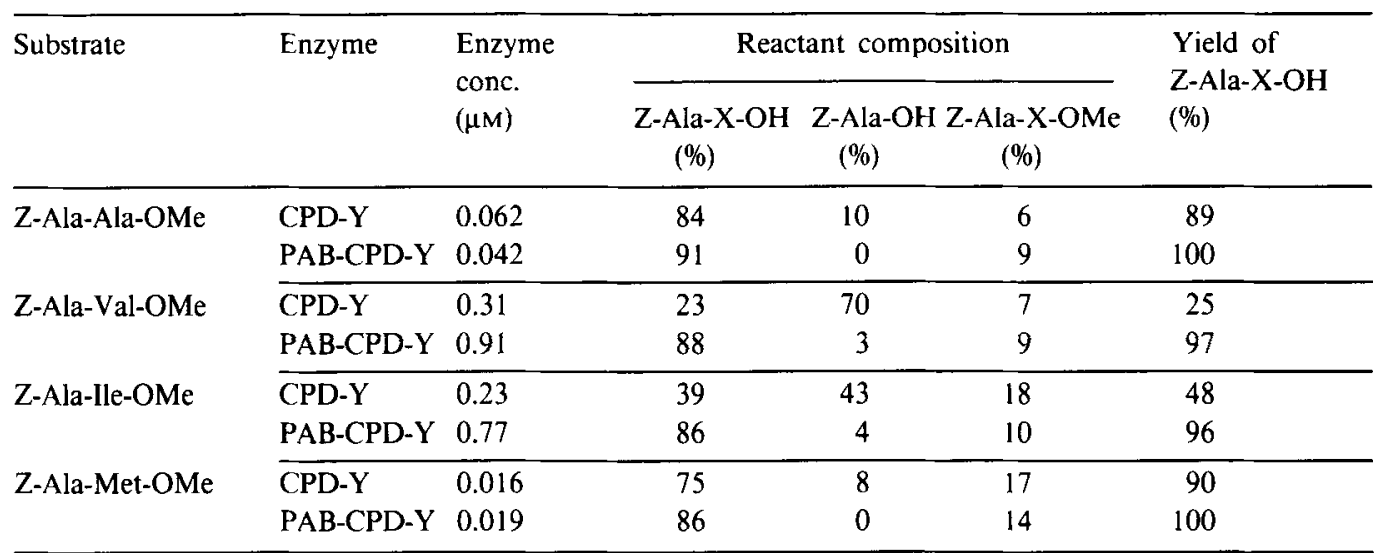

Reaction conditions: 2 mM-substrate, 1 mM-EDTA, 10\% DMF, pH 7.5, $22{ }^{\circ} \mathrm{C}$. Reaction time: $11-31$ min. The reactant composition was determined by HPLC. 
NPAB-CPD-Y, m-NPAB-CPD-Y, IAA-CPD-Y and unmodified CPD-Y, respectively. Thus, it appears that PAB-CPD-Y is the most specific deamidase among the derivatives of CPD-Y described in section 3.1.

\subsection{Applications of alkylated CPD-Y derivatives in removal of ester groups from peptide esters}

It has previously been demonstrated that CPD-Y exhibits high esterase activity and low peptidase activity at basic $\mathrm{pH}$ values $(15,18)$ such that it can be employed to remove ester groups from the C-terminus of peptide esters, essentially without further degrading the unblocked peptide (26). However, the high esterase activity and extremely low peptidase activity of the alkylated CPD-Y derivatives (see section 3.2) suggested that these enzymes might catalyze the removal of ester groups even more specifically than unmodified CPD-Y. To confirm this the time courses for the action of CPD-Y and PAB-CPD-Y on Z-Ala-Ile-OMe were compared at pH 7.5 (Figure 8). With CPD-Y (Panel A) two products were formed: Z-Ala-Ile-OH by release of methanol via the esterase activity of $\mathrm{CPD}-\mathrm{Y}$ and Z-Ala-OH by release of $\mathrm{H}-\mathrm{Ile}-\mathrm{OH}$ via the peptidase activity of CPD-Y. The maximum content of Z-Ala-Ile-OH in the reaction mixture was only $39 \%$ since it was further degraded to Z-Ala-OH and $\mathrm{H}-\mathrm{Ill}-\mathrm{OH}$. In contrast, with PAB-CPD-Y (Panel B) Z-Ala-Ile-OH was formed in almost quantitative yield and the amount decreased only slightly through the reaction, demonstrating that PAB-CPD-Y indeed is a much more specific esterase than unmodified CPD-Y. A series of similar ester substrates with the general formula Z-Ala-X$\mathrm{OMe}$, where $\mathrm{X}=$ amino acid residue, were treated with the two enzymes (Table VI) and in all cases were the yields of Z-Ala-X-OH higher with PAB-CPD-Y than with unmodified CPD$Y$. However, the magnitude of the difference varied, suggesting that the nature of $X$ influences the ratio of esterase activity towards Z-Ala-X$\mathrm{OMe}$ and peptidase activity towards Z-Ala-X$\mathrm{OH}$.

\section{DISCUSSION}

The experiments described in the present work demonstrate that iodoacetamide alkylates a single methionyl residue in CPD-Y and since the competitive inhibitor $Z$-ala-Phe-OH (1) protects the enzyme against inactivation this residue presumably is located in the active site. It is reasonable to assume that it is the same methionyl residue which is modified with the other reagents employed in the present study, i.e. phenacylbromide, m-nitrophenacylbromide, and p-nitrophenacylbromide, since only the methionine content of CPD-Y appeared to be affected by the modifications and treatment of PAB-CPD-Y with mercaptoethanol fully restored the peptidase activity.

The alkylated derivatives of CPD-Y, i.e. IAACPD-Y, PAB-CPD-Y, m-NPAB-CPD-Y, and p-NPAB-CPD-Y were kinetically characterized. $\mathrm{k}_{\mathrm{cat}} / \mathrm{K}_{\mathrm{m}}$ for the hydrolysis of FA-Phe-OMe, $\mathrm{FA}$ Leu-OMe, FA-Phe-OEt and FA-Ala-OEt by IAA-CPD-Y is $30-75 \%$ of the values obtained with unmodified CPD-Y. These reductions in $\mathrm{k}_{\mathrm{cat}} / \mathrm{K}_{\mathrm{m}}$, which are due to both a decrease in $\mathrm{k}_{\mathrm{cat}}$ and an increase in $K_{m}$, exhibit no apparent relation to the structure of these ester substrates. However, $k_{\text {cat }} / K_{m}$ for the hydrolysis of FA-AlaOBzl by IAA-CPD-Y is only approximately $5 \%$ of the value obtained with unmodified CPD-Y suggesting that the alkyl sulfonium group introduced into the enzyme due to steric hindrance prevents a favourable interaction with the bulky leaving group of the benzyl ester substrate. This explanation is in accordance with results obtained with PAB-CPD-Y which contains the more bulky phenacyl sulfonium group. With this enzyme $k_{\text {cat }} / K_{m}$ for the hydrolysis of the methyl esters FA-Phe-OMe and FA-Leu-OMe were found to be 3-5 fold higher than those obtained with unmodified CPD-Y due to a significant decrease in $\mathrm{K}_{\mathrm{m}}$ while $\mathrm{k}_{\text {cat }} / \mathrm{K}_{\mathrm{m}}$ for the PAB-CPD-Y catalyzed hydrolysis of the ethyl esters FA-Phe-OEt and FA-Ala-OEt and in particular the benzyl ester FA-Ala-OBzl were significantly lower than with unmodified CPD-Y due to both a decrease in $k_{\text {cat }}$ and an increase in $\mathrm{K}_{\mathrm{m}}$. Thus, introduction of a phenacylsulfonium ion into the active site of CPD-Y affects the specificity of the enzyme with respect to the leaving group of ester substrates such that 
methyl esters, characterized by non-bulky leaving groups, are hydrolysed at elevated rates relative to unmodified CPD-Y whereas ethyl and benzyl esters, characterized by more bulky leaving groups, are hydrolyzed at reduced rates. Since the acylation step might be the rate-limiting step in the CPD-Y catalyzed hydrolysis of ester substrates $(2,6)$ it may be assumed that $K_{m}$ reflects the dissociation constant of the enzyme-substrate complex $\left(\mathrm{K}_{s}\right)$ and that $\mathrm{k}_{\text {cat }}$ is a good measure for the rate-constant of the acylation step $\left(\mathrm{k}_{2}\right)$. Thus, it can be inferred that relative to unmodified CPD-Y, PAB-CPD-Y binds methyl esters better while ethyl and benzyl esters are bound worse. These differences between CPD-Y and PAB-CPD-Y indicate that the methionine being modified by phenacylbromide is located at the $S_{1}^{\prime}$ binding site of the enzyme.

Introduction of a nitro group at the para-position of the phenacylsulfonium group, viz. pNPAB-CPD-Y, caused a significant increase in $\mathrm{k}_{\mathrm{cat}}$ for the hydrolysis of all ester substrates regardless of the size of the leaving group, while a nitro group at the meta-position, viz. $\mathrm{m}$ NPAB-CPD-Y, had only a slight influence on $\mathrm{k}_{\text {cat }}$. This suggests that the position of the nitro group within the $S_{1}^{\prime}$ binding site influences the rate of acylation. The introduction of a nitro group in the meta-position and in particular the para-position of the phenacylsulfonium group also caused an increase in $\mathrm{K}_{\mathrm{m}}$ for the hydrolysis of methyl and ethyl ester substrates suggesting an adverse effect on the binding of such substrates.

Introduction of an alkylsulfonium group into the $S_{1}$ binding site of CPD-Y influenced the amidase and peptidyl amino acid amide hydrolase activities towards peptide amides in a manner which was similar to the influence on ester substrates, i.e. the effects depended on the size of the leaving group of the substrates. Thus, relative to CPD-Y, $\mathrm{k}_{\mathrm{cat}} / \mathrm{K}_{\mathrm{m}}$ for the PAB-CPD-Y, $m-N P A B-C P D-Y$, and p-NPAB-CPD-Y catalyzed hydrolysis of FA-Val $=\mathrm{NH}_{2}$, FA-Leu $-\mathrm{NH}_{2}$ and FA-Phe- $\mathrm{NH}_{2}$, which all contain a small leaving group, were significantly increased while a reduction was observed in $\mathrm{k}_{\mathrm{cat}} / \mathrm{K}_{\mathrm{m}}$ for the hydrolysis of FA-Phe $\downarrow$ Gly- $\mathrm{NH}_{2}$ and FAPhe- Val- $\mathrm{NH}_{2}$, both of which contain more bulky leaving groups. The fact that $\mathrm{k}_{\mathrm{cat}} / \mathrm{K}_{\mathrm{m}}$ for the hydrolysis of FA-Phe $-\mathrm{Val}-\mathrm{NH}_{2}$ was reduced much more than that for the hydrolysis of FA-Phe-Gly- $\mathrm{NH}_{2}$, suggests that it is primarily the ability of the enzyme to bind the side-chain of the C-terminal amino acid in peptide amides which is adversely affected by the introduction of the phenacyl group or one of its nitro analoges at this position. This confirms that the methionyl residue being modified by these alkylating reagents is located in the $S_{i}$ binding site and presumably in the binding pocket for $R$, which accordingly, as suggested in Figure 1, also serves as binding site for bulky leaving groups of ester substrates. Modificatiqn of CPD-Y with iodoacetamide similarly caused a reduction in $\mathrm{k}_{\text {cal }} /$ $\mathrm{K}_{\mathrm{m}}$ for the hydrolysis of FA-Phe-Gly- $\mathrm{NH}_{2}$ and FA-Phe $-V$ al- $\mathrm{NH}_{2}$ but in addition, a reduction in $k_{\text {cat }} / K_{m}$ was observed for the hydrolysis of FA-Val- $\mathrm{NH}_{2}$, FA-Leu- $\mathrm{NH}_{2}$ and FA-Phe- $\mathrm{NH}_{2}$, i.e. substrates with small leaving groups. Since IAA-CPD-Y also hydrolysed FA-Phe-OMe and FA-Leu-OMe with reduced $k_{\text {cat }} / K_{m}$ it appears that the alkylated enzyme hydrolyses substrates with small leaving groups at higher rates than unmodified CPD-Y only when a sulfonium ion plus a bulky hydrophobic group is introduced into the $S_{1}^{\prime}$ binding site.

Modification of the methionyl residue in the $S$; binding site of CPD-Y affects the ability of the enzyme to hydrolyse peptide substrates in a manner which is rather independent of the bulkiness of both the group introduced into the enzyme and the leaving group of the substrate. In all cases $k_{\text {cat }}$ is drastically reduced while $\mathbf{K}_{m}$ is only slightly increased and, since $K_{m}$ in CPD-Y catalyzed peptide hydrolysis is a good measure for $K_{s}$, these results suggest that the postulated positively charged binding site which is expected to function when the enzyme forms tight complexes with peptide substrates (see section 1) is not affected by the alkylation of the methionyl residue. This is consistent with the fact that the $\mathrm{pH}$ dependence of $\mathrm{K}_{\mathrm{m}}$ for peptide hydrolysis remains unchanged by the modification with phenacylbromide relative to CPD-Y, and that a methionyl side-chain is uncharged and hardly could constitute a binding site for the carboxylate group of peptide substrates. The present results do not explain the drastic decrease in 
$\mathrm{k}_{\mathrm{cal}}$ but it may be speculated that the sulfonium ion interferes with a conformational change which might be esssential for the high $\mathrm{k}_{\text {cat }}$ values of peptide hydrolysis. The fact that hydrolysis of ester and amide substrates is adversely affected only when the leaving group of the substrate is bulky would then suggest that such a conformational change is not essential for the hydrolysis of substrates with blocked C-terminus.

The increased amidase activity of PAB-CPD$Y, m-N P A B-C P D-Y$ and $p-N P A B-C P D-Y$ suggested that these enzymes might have applications as deamidases. In the action of CPD-Y on peptide amides the yield of deamidation is determined by the rates of reactions I and II in Scheme 2 but the influence of the C-terminal sequence has not been established since the low solubility of peptide amides prevents detailed kinetic studies. However, for ester (6) and peptide substrates (15) it has been shown that substrates with Phe, Leu, Met, or Ala in the $P_{1}$ position, i.e. the amino acid residue which acylates the enzyme, are hydrolyzed much faster than those with Gly, His, Ser, Ile, or Val at this position. With peptide amides of the structure $\mathrm{X}-\mathrm{A}-\mathrm{B}-\mathrm{NH}_{2}$ both $\mathrm{A}$ and $\mathrm{B}$ can acylate the enzyme as indicated in Figure 1 and it appears that A preferentially acylates the enzyme when $A$ is such a "fast" amino acid residue and $B$ a "slow" amino acid residue, e.g. Bz-Ala-Val$\mathrm{NH}_{2}$, Z-Ala-Ser- $\mathrm{NH}_{2}$, and FA-Phe-Gly- $\mathrm{NH}_{2}$. In these cases low yields of deamidation were obtained. On the other hand, B preferentially acylates the enzyme when $A$ is a "slow" amino acid residue and $B$ a "fast" amino acid residue, e.g. Z-Ile-Ala- $\mathrm{NH}_{2}$, Z-Val-Ala- $\mathrm{NH}_{2}$, and Z-GlyAla- $\mathrm{NH}_{2}$, and in these cases high yields of deamidation were obtained. Accordingly, when both A and B are either "slow" amino acid residues, i.e. Z-Val-Gly- $\mathrm{NH}_{2}$, or "fast" amino acid residues, e.g. Bz-Ala-Phe- $\mathrm{NH}_{2}$ and Bz-AlaAla- $\mathrm{NH}_{2}$, intermediary yields of deamidation were obtained. Although this represents a simplified treatment of the results it is apparent that the reaction course in deamidation reactions to a large extent is determined by the side-chain specificity of CPD-Y with respect to the $P_{1}$ position of the substrate.

When the deamidation reactions were per- formed with PAB-CPD-Y the C-terminal sequence of the peptide amides did not influence the yield of deamidation to the extent observed with CPD-Y. With the exception of peptide amides containing glycyl or seryl residues at the C-terminal position the yields of deamidation with this enzyme varied between $80 \%$ and $100 \%$ which represent a significant increase relative to unmodified CPD-Y. These results reflect that introduction of the bulky phenacyl group into the $S_{i}^{\prime}$ binding site of the enzyme caused a drastic increase in the ratio of amidase to peptidyl amino acid amide hydrolase activity towards peptide amides containing an amino acid residue with a hydrophobic and/or bulky side-chain at the C-terminal position. The yields of deamidation using m-NPAB-CPD- $Y$ and p-NPABCPD-Y were also higher than with unmodified CPD-Y but in general somewhat lower than with PAB-CPD-Y. However, with IAA-CPD-Y, characterized by a much less bulky sulfonium group, the yields of deamidation were essentially identical to those obtained with unmodified CPD-Y. Thus, in accordance with the results of the kinetic studies it is conceivable that the bulky phenyl group of PAB-CPD-Y exerts its influence on deamidation reactions by impeding the entrance of hydrophobic and bulky amino acid side-chains into the binding pocket for $R_{t}$ in the $S_{i}$ binding site (see Figure 1).

In the synthesis of peptide bonds by aminolysis of peptide esters high yields are generally obtained when amino acid amides are used as nucleophiles in the reactions catalyzed by serine carboxypeptidases and serine endopeptidases $(11,20,22,32)$. The peptide amides formed in such reactions must be deamidated before the further elongation of the peptide chain can proceed, and it is conceivable that the alkylated derivatives of CPD-Y described in the present paper and in particular PAB-CPD-Y can be successfully employed for this purpose.

In conventional peptide synthesis ester groups can be used to protect carboxylic acid groups but this requires that the ester group subsequently can be removed without otherwise affecting the elongated peptide. ROYER (26) has previously demonstrated that the high esterase and low peptidase activity of CPD-Y at $\mathrm{pH}>8$ renders this enzyme a useful tool in such reac- 
tions. However, observations in this laboratory suggest that CPD-Y even under these conditions exhibits significant peptidase activity, in particular towards peptides with hydrophobic amino acid residues at the $P_{1}$ and $P_{1}^{\prime}$ positions. Thus, after removal of the ester group from the peptide ester CPD-Y may degrade the unblocked peptide. Since PAB-CPD-Y, and presumably also the other alkylated derivatives removes ester groups from peptide esters more specifically than unmodified CPD-Y these enzymes may be useful in such reactions as well.

The results described in the present paper demonstrate that modifications of amino acid side-chains located at the binding sites of CPD-Y may perturb the interactions with substrates such that the specificity is altered and similar results have also been obtained by modification of the sulfhydryl group located in the $S$, binding site of CPD-Y with mercurials (6). The fact that all these CPD-Y derivatives with advantage can be used in place of unmodifed CPD-Y in certain processes concerning enzymatic peptide synthesis $(7,10)$ is of interest since they represent examples of how enzymes may be tailored to specific processes by "protein engineering".

\section{ACKNOWLEGEMENTS}

I am indepted to Professor MARTIN OTTESEN for invaluable advise during the work and for critically revising the manuscript. Ms. IRENE SIMONSEN is acknowledged for excellent technical assistance.

\section{REFERENCES}

1. BaI, Y., R. HaYashi \& T. Hata: Kinetic studies of carboxypeptidase Y. II. Effects of substrate and product analogs on peptidase and esterase activities. J. Biochem. 77, 81-88 (1975)

2. BaI, Y., R. Hayashi \& T. Hata: Kinetic studies of carboxypeptidase Y. III. Action on ester, amide, and anilide substrates and the effects of some environmental factors. J. Biochem. 78, 617-626 (1975)

3. Blumberg, S. \& B.L. VAlleE: Superactivation of thermolysin by acylation with amino acid N-hydroxysuccinimide esters. Biochemistry 14, 24102419 (1975)
4. BREDDAM, K., F. WidMER \& J.T. JohanSEN: Carboxypeptidase $Y$ catalyzed transpeptidations and enzymatic peptide synthesis. Carlsberg Res. Commun. 45, 237-247 (1980)

5. BREDDAM, K., F. WIDMER \& J.T. JohANSEN: Influence of the substrate structure on carboxypeptidase $Y$ catalyzed peptide bond formation. Carlsberg Res. Commun. 45, 361-367 (1980)

6. BREDDAM, K.: Modification of the single sulfhydryl group of carboxypeptidase $Y$ with mercurials. Influence on enzyme specificity. Carlsberg Res. Commun. 48, 9-19 (1983)

7. BREDDAM, K., F. WidMER \& J.T. JOHANSEN: Amino acid methyl esters as amine components in CPD-Y catalyzed peptide synthesis: Control of side reactions. Carlsberg Res. Commun. 48, 231237 (1983)

8. Breddam, K., S. Sørensen \& M. OtTesen: Isolation of a carboxypeptidase from malted barley by affinity chromatography. Carlsberg Res. Commun. 48, 217-230 (1983)

9. BREDdAM, K. \& M. OtTESEN: Influence of guanidine derivatives on the specificity of malt carboxypeptidase. Carlsberg Res. Commun. 48, 573582 (1983)

10. Breddam, K. \&. J.T. Johansen: Semisynthesis of human insulin utilizing chemically modified carboxypeptidase Y. Carlsberg Res. Commun. 49, 463-472 (1984)

11. Breddam, K. \& M. Ottesen: Malt carboxypeptidase catalyzed aminolysis reactions. Carlsberg Res. Commun. 49, 473-481 (1984)

12. Coletti-Previero, M.-A., A. Previero \& E. ZUCKERKANDL: Separation of the proteolytic and esterasic activities of trypsin by reversible structural modifications. J. Mol. Biol. 39, 493-501 (1969)

13. FruTON, J.S.: Proteinase-catalyzed synthesis of peptide bonds. Ed. A. Meister, John Wiley, New York. Adv. Enzymol. 53, 239-306 (1982)

14. Gundlach, H.G., S. Moore \& W.H. Stein: The reaction of iodoacetate with methionine. J. Biol. Chem. 234, 1761-1764 (1959)

15. HaYashi, R., Y. Bai \& T. Hata: Kinetic studies of carboxypeptidase Y. I. Kinetic parameters for the hydrolysis of synthetic substrates. J. Biochem. 77, 69-79 (1975)

16. Holmquist, B., S. BlumberG \& B.L. VAlLEE: Superactivation of neutral proteases: acylation with $\mathrm{N}$-hydroxysuccinimide esters. Biochemistry 15 , 4675-4680 (1976)

17. InAGami, T. \& T. MURACHI: The mechanism of the specificity of trypsin catalysis. J. Biol. Chem. 239, 1395-1401 (1964)

18. Johansen, J.T., K. BREddam \& M. OtTesen: Iso- 
lation of carboxypeptidase $\mathrm{Y}$ by affinity chromatography. Carlsberg Res. Commun. 41, 1-14 (1976)

19. KUhN, R.W., K.A. Walsh \& H. NeURath: Reaction of carboxypeptidase $C$ with group-specific reagents. Biochemistry 15, 4881-4886 (1976)

20. Morihara, K. \& T.OKA: $\alpha$-chymotrypsin as the catalyst for peptide synthesis. Biochem. J. 163, 531-542 (1977)

21. NAIDER. F. \& Z. BOHAK: Regeneration of methionyl residues from their sulfonium salts in peptides and proteins. Biochemistry 11, 3208-3211 (1972)

22. OKA, T. \& K. MORIHARA: Trypsin as catalyst for peptide synthesis. J. Biochem. 82, 1055-1062 (1977)

23. Quiocho, F.A. \& W.N. Lipscomb: Carboxypeptidase A: A protein and an enzyme. Academic Press, N.Y., Eds. C.B. Anfinsen, J.T. Edsall \& F.M. Richards. Adv. Prot. Chem. 25, 1-53 (1971)

24. Riordan, J.F. \& B. L. VALleE: Reactions with $\mathrm{N}$-ethylmaleimide and p-mercuribenzoate. Ed. C.H.W. Hirs. Methods. Enzymol. 11, 541-548 (1967)

25. RIORDAN, J.F.: Functional arginyl residues in carboxypeptidase A. Modification with butanedione. Biochemistry 12, 3915-3923 (1973)

Accepted by: H. Klenow, E. Lund and S. O. Andersen
26. Royer, P.G. \& G. M. Anantharmaiah: Peptide synthesis in water and use of immobilized carboxypeptidase Y for deprotection. J. Am. Chem. Soc. 101, 3394-3396 (1979)

27. SCHeChter, I. \& A. Berger: On the size of the active site of proteases. I. Papain. Biochem. Biophys. Res. Commun. 27, 157-167 (1967)

28. SEGEL, I.: Biochemical calculations. John Wiley \& Sons, New York, pp. 393-395 (1968)

29. SVENDSEN, I.: Chemical modifications of the subtilisins with special reference to the binding of large substrates. A review. Carlsberg Res. Commun. 41, 237-291 (1976)

30. WidMeR, F. \& J.T. JOHANSEN: Enzymatic peptide synthesis. Carboxypeptidase Y catalyzed formation of peptide bonds. Carlsberg Res. Commun. 44, 37-46 (1979)

31. WidMer, F., K. BREdDam, \& J.T. Johansen: Carboxypeptidase $Y$ catalyzed peptide synthesis using amino acid alkyl esters as amine components. Carlsberg Res. Commun. 45, 453-463 (1980)

32. WIDMER,F., K. BREDDAM, \& J.T. JOHANSEN: Influence of the structure of amine components in carboxypeptidase Y catalyzed amide bond formation. Carlsberg Res. Commun. 46, 97-106 (1981) 